\title{
Mochammad Natsir dan Pemikiran Ekonomi Ummat 1950-1960
}

\author{
Imas Emalia ${ }^{1}$
}

\begin{abstract}
This article is intended as an attempt to reconstruct the history of thought from a figure of the famous politician who is soft, firm, and islamic behave, Mochammad Natsir. His thoughts about the economy of the Muslims is as his fight in Indonesia people's destinies take notice, especially Muslims. During his life in pursuit of economic Natsir Mochammad Muslims either when he politicking, of community, and preaching. Related to the economic development of this Ummah, Mochammad Natsir championed economic development via the Ummah Party Mayumi, the largest Islamic Ummah as the party at the time. In discussing character Mochammad Natsir, has always been in the political discussion, whether its action in politics or also his idea about politics that inevitably associated with Islam, very little discussion about his thinking in the field of Economics, but it turns out that economics is concerned Natsir Mochammad Ummah, generally the people of Indonesia. His thoughts on the economy is very inspiring and uplifting for the people of Indonesia to be able to maintain his life struggling to avoid poverty, squalor, misery, and suffering due to the behavior of those who blackmail her life wander the property. His idea about Islamic economic development Mochammad Natsir Ummah who looks at and strive to let the Muslims during the post-revolution until the 1960 's can live peaceful, prosperous, far from suffering, poverty, misery, and always pay attention to the messages from the teachings of Islam. Message from thinking this is about Mochammad Natsir human duty to care for and respect each other, because that is the nature of a human being as an independent creature who had to work hard in the face of the Earth to avoid poverty. This paper, entitled "the Economic Thinking and Natsir Mochammad Ummah 1950-1960".
\end{abstract}

Keywords: Mohammad Natsir, figures, economy, thoughts, poverty.

\section{Abstrak}

Makalah ini dimaksudkan sebagai usaha merekonstruksi sejarah pemikiran dari seorang sosok politikus terkenal yang lembut, tegas, dan islami, yakni Mochammad Natsir. Pemikirannya tentang ekonomi ummat adalah sebagai perjuangannya dalam memperhatikan nasib rakyat Indonesia, terutama ummat Islam. Selama hidupnya Mochammad Natsir memperjuangkan ekonomi ummat baik ketika ia berpolitik, bermasyarakat, dan berdakwah. Terkait dengan pembangunan ekonomi ummat ini, Mochammad Natsir memperjuangkan pembangunan ekonomi ummat melalui Partai Mayumi, sebagai partai ummat Islam terbesar saat itu. Dalam membahas tokoh Mochammad Natsir, selama ini selalu pada pembahasan politik, baik kiprahnya dalam berpolitik atau juga pemikiran-pemikirannya tentang politik yang pasti dikaitkan dengan Islam, sangat sedikit pembahasan tentang pemikirannya di bidang ekonomi, padahal ternyata Mochammad Natsir sangat memperhatikan ekonomi ummat Islam, umumnya rakyat Indonesia. Pemikirannya tentang ekonomi sangat memberikan inspirasi dan semangat bagi rakyat Indonesia untuk dapat berjuang mempertahankan hidupnya yang terhindar dari kemiskinan, kemelaratan, kesengsaraan, dan penderitaan akibat perilaku pemerasan dari mereka yang hidupnya bergelimang harta. Untuk itu makalah ini akan menyoroti Pemikiran Mochammad Natsir tentang pembangunan ekonomi ummat yang memandang dan mengusahakan agar umat Islam pada periode pasca revolusi sampai tahun 1960 dapat hidup damai, sejahtera, jauh dari penderitaan, kemiskinan, kesengsaraan, dan senantiasa memperhatikan pesan-pesan dari ajaran agama Islam. Pesan dari pemikiran Mochammad Natsir ini adalah tentang tugas manusia untuk menjaga dan menghormati sesamanya, karena itu adalah fitrah seorang manusia sebagai makhluk yang merdeka yang harus bekerja keras di muka bumi untuk menghindari kemiskinan. Makalah ini berjudul "Mochammad Natsir dan Pemikiran Ekonomi Ummat 1950-1960".

Kata kunci : Mochammad Natsir, tokoh, ekonomi, pemikiran, kemiskinan.

\footnotetext{
${ }^{1}$ Fakultas Adab dan Humaniora UIN Syarif Hidayatullah Jakarta.
} 


\section{A. Latar Belakang}

Berdirinya partai-partai Islam pada masa kemerdekaan perlu dilihat dengan latar belakang politik di Indonesia pada masa-masa tersebut. Kondisi bangsa Indonesia pada awal abad XX berada dalam kemiskinan, kesengsaraan, kefakiran, dan kesenjangan sosial yang tinggi. Adanya partai-partai Islam itu, yang muncul sejak awal revolusi dan semakin berpengaruh pada masa Demokrasi Liberal, menjadikan partaipartai Islam tersebut sebagai tumpuan bagi pembangunan ummat Islam ke arah yang lebih baik dan sejahtera. Bagi ummat Islam Indonesia kemiskinan haruslah diperhatikan dan diprihatinkan untuk kemudian diatasi atau dicarikan solusinya. Hal ini karena mereka yang berada di garis kemiskinan tidak hanya menderita secara riil, tetapi juga secara psikologis, karena perbedaan kesejahteraan yang mencolok dengan mereka yang hidup berlimpah harta akan dapat menimbulkan kecemburuan. Oleh karena itu perbedaan inilah yang harus dihilangkan, baik melalui pelaksanaan ajaran agama seperti zakat maupun upaya-upaya kelompok masyarakat maupun pemerintah.

Menurut Dr. Sumitro Djojohadikusumo, bahwa pembangunan ekonomi Indonesia pada hakekatnya adalah pembangunan ekonomi baru, dan yang perlu dilakukan itu adalah mengubah struktur ekonomi umumnya dari ekonomi kolonial ke ekonomi nasional. Sumitro kemudian menerapkannya pada ekonomi perdagangan. Menurutnya bahwa bangsa Indonesia harus secepat mungkin dimunculkan kelas pengusaha. Para pengusaha Indonesia yang bermodal rendah diberi kesempatan untuk berpartisipasi membangun ekonomi nasional. Gagasan Sumitro ini kemudian dituangkan dalam Kabinet Natsir (September 1950 - April 1951), ketika itu Sumitro menjabat sebagai Menteri Perdagangan. Program ini kemudian dikenal dengan sebutan Program Benteng (Benteng Group). Program pemerintah ini pada hakekatnya adalah kebijaksanaan untuk melindungi usahausaha pribumi. Walaupun pada akhirnya program ini tidak berhasil karena banyak pengusaha yang tidak sesuai dengan aturan kerja yang sudah ditentukan dan banyak mencari keuntungan sendiri. Tetapi pemerintah saat itu sudah memikirkan perkembangan ekonomi rakyat yang dapat mensejahterakan rakyat dari tahun-tahun sebelumnya. ${ }^{2}$

Terkait dengan pembangunan ekonomi, Mochammad Natsir juga memperjuangkan pembangunan ekonomi ummat melalui Partai Mayumi, partai ummat Islam terbesar saat itu. Pembangunan ekonomi ummat ini dapat dilihat dari beberapa hal sebagai berikut; dalam Kongres Masyumi tahun 1952 mengesahkan beberapa program perjuangan Masyumi yang ingin ditegakkan dalam hidup bernegara. Program ini terbagi tujuh bagian: kenegaraan, perekonomian, keuangan, sosial, pendidikan dan kebudayaan, luar negeri, dan Irian Barat. Dalam bidang perekonomian, Masyumi mengatur menurut dasar ekonomi terpimpin. Dalam bukunya, Deliar Noer menjelaskan tentang program ekonomi Partai Masyumi ini, sebagai berikut:

Perencanaan produksi dan distribusi penting untuk kesejahteraan rakyat seluas-luasnya. Monopoli oleh perusahaan swasta dilarang, dan konkurensi hendaknya bersifat membangun. Politik harga dan upah hendaknya sesuai "dengan perekonomian dalam negeri". Koperasi harus dibangun dengan bantuan pemerintah.perusahaan-perusahaan vital

\footnotetext{
${ }^{2}$ Marwati Djoened Poesponegoro, Nugroho Notosusanto, ed., Sejarah Nasional Indonesia VI, Jakarta, Balai Pustaka, 1984, hal. 240-241
} 
hendaklah dinasionalisasi. Industrialisasi dimaksudkan untuk membebaskan Indonesia sebanyak-banyaknya dari keperluan impor, dan untuk mengadakan lapangan kerja, terutama di daerahdaerah yang penduduknya padat. Modal asing dibenarkan atas dasar "saling menguntungkan". Pemerintah harus memberi perlindungan kepada para petani dengan memberantas pemerasan terhadap mereka; menghapuskan sistem tuan tanah menurut hukum dan membagi-bagikan tanahnya kepada petani; membangun koperasi; menjamin harga penjualan yang layak bagi hasil tani dan upah minimum. Pemerintah juga harus membantu nelayan dengan membantu koperasi; mengadakan latihan-latihan; memodernisasikan alat, pelabuhan perikanan dan menjamin harga penjualan. Undang-undang Agraria perlu disesuaikan dengan kepentingan masyarakat. Politik agraria ditujukan pada usaha-usaha melipatgandakan produksi pertanian, terutama bahan makanan. Pemerintah hendaknya juga memberi kemudahan bagi golongan menengah Indonesia untuk berkembang dan memperkuat kedudukannya. Golongan ini menurut Masyumi penting secara politik dan sosial. $^{3}$

Masyumi didirikan atas dasar citacita dan pandangan hidup umat Islam Indonesia dengan tujuan sebagai berikut, pertama; kemerdekaan jiwa tiap-tiap orang perseorangan, daripada kemusyrikan, takhyul, dan rasa takut. Rasa takut kepada selain kepada Allah Pencipta Seluruh Alam, yakni dengan menegakkan kalimatul-tauhid. Kedua; pembebasan manusia dari penindasan dan pemerasan manusia dan golongan oleh golongan dalam bentuk apapun juga. Ketiga; pembebasan manusia dari

${ }^{3}$ Deliar Noer, Partai Islam di Pentas Nasional: Kisah dan Analisis Perkembangan Politik Indonesia 1945 1965, Bandung, Mizan, 2000, hal. 148-150 tindakan kemelaratan dan kemiskinan, kefakiran yang menjadi sumber kekufuran. Keempat; pembebasan manusia daripada sifat ta'ashub (chauvinism), ataupun ta'ashub dalam lapangan kepercayaan dan keagamaan yang dapat menjadi pangkal perpecahan antar bangsa bahkan juga antar agama. Kelima; menegakkan satu masyarakat hidup yang didasarkan kepada musyawarah dengan menghargai nilainilai manusia (human dignity), atas dasar hidup dan memberi hidup, bukan atas dasar siapa kuat, siapa di atas, siapa lemah, siapa mati (survival of the fiftest). ${ }^{4}$

Berasarkan cita-cita dan pandangan Partai Masyumi tersebut, Mochammad Natsir selalu memperhatikan nasib rakyat Indonesia dan terutama sesama ummatnya. Mochammad Natsir berusaha mengamalkan apa yang diajarkan dalam agama Islam bahwa di dalam Al-Qur'an surat An-Nisa (QS. 4: 1) disebutkan "orang-orang mukmin adalah bersaudara dan bahwa manusia yang taqwa adalah yang selalu menjaga hubungan silaturrahmi". Dari ayat tersebut Mochammad Natsir menyimpulkan bahwa bangsa menurut agama Islam adalah suatu keluarga besar yang tidak saling bersaing yang bertujuan atau berakibat mematikan satu sama lain, tetapi selalu berusaha untuk bekerja sama dalam kehidupan ekonomi dan sosial yang akrab. Tidak saja itu Mochammad Natsir juga banyak memperhatikan ayat-ayat Al-Qur'an yang berisi tentang keadilan dan pemerataan dalam pembagian pendapatan dan kekayaan. Surat Fushilat

\footnotetext{
${ }^{4}$ Diambil dari pidato Mohammad Natsir pada tanggal 7 November 1956, pada saat peringatan Masyumi kesebelas. Naskah lengkap pidato ini dimuat dalam harian Abadi, pada tanggal 9, 10, 12, November 1956. Herbert Feith \& Lance Castles, ed., Pemikiran Politik Indonesia 1945-1965, LP3ES, Jakarta, 1995, hal. 211213
} 
(Q.S 41: 10) menunjukkan kemurahan Allah yang membagi rezeki serba cukup bagi semua orang yang akan memerlukannya, tetapi dalam pembagiannya biasanya tidak merata sehingga harus diatur secara khusus agar lebih merata (Al-Hadid/Q.S. 57: 7). Bahwa rezeki diberikan "serba cukup" tidaklah berarti manusia tidak perlu bekerja keras untuk memperoleh rezeki tersebut. Justru sebaliknya manusia diharuskan bekerja dan berusaha (AtTaubah/Q. S. 9: 105) bahkan segera setelah shalat Jum'at (Al-Jumu'ah/Q. S. 62: 10).

Oleh karena itu dalam Islam lembaga zakat diadakan untuk mengurangi ketimpangan dalam pembagian pendapatan dan kekayaan nasional. Fakir miskin merupakan tujuan utama penggunaan zakat. Ajaran Islam tentang pengaturan zakat ini menunjukkan komitmen ummat Islam untuk mengatasi kemiskinan dan kesenjangan sosial dan sangat membenci hidup yang bermegah-megahan dan melupakan nasib ummat di sekitarnya.

Berdasarkan kajian Deliar Noer, bahwa rencana Partai Masyumi dalam memperjuangkan perekonomian rakyat adalah bertujuan agar umat Islam tidak terjebak dalam kemelaratan dan kemiskinan serta kefakiran yang dianggap sebagai sumber dari kekufuran. Dalam hal ini, Mochammad Natsir melalui Partai Masyumi-nya tidak mengesampingkan nasib para petani, dan memperjuangkan mereka agar tidak terjebak dalam sistem pemerasan dan sistem tuan tanah yang mencekik kehidupannya. $^{5}$ Rencana ini sesuai dengan ajaran Islam, bahwa kegiatan berdakwah merupakan kewajiban bagi setiap muslim. Gerakan dakwah adalah suatu sifat yang logis dari penjabaran ajaran Islam sebagaimana tercantum dalam Al Qur'an surat Ali Imran ayat 104 yang artinya sebagai berikut: "dan

${ }^{5}$ Deliar Noer, op. cit. hendaklah ada di antara kamu segolongan umat yang menyeru kepada kebajikan, menyuruh kepada yang ma'ruf dan mencegah dari yang munkar..."

Tentang memperjuangkan pembangunan ekonomi ummat ini, Mochammad Natsir memandang dan mengusahakan agar umat Islam dapat hidup damai, sejahtera,dan jauh dari kemiskinan, manusia sebagai makhluk yang merdeka maka harus bekerja keras di muka bumi untuk menghindari kemiskinan, tidak bisa dilaluinya dengan hanya berharap sambil bertopang dagu menunggu rizki yang akan datang. Pemikirannya ini selain lewat dakwah, berpolitik, juga lewat tulisan-tulisan baik berupa buku, atau pemberitaanpemberitaan dan artikel-artikel dalam surat kabar, terutama harian Abadi, yaitu surat kabar harian milik Partai Islam Masyumi. Bagi Mochammad Natsir menyampaikan ide-ide atau op merupakan bagian dari dakwahnya dalam mengajak kepada kebaikan, karena akan digunakan oleh banyak orang.

\section{B. Partai Masyumi dan Pemikiran Mochammad Natsir tentang Pembangunan Ekonomi Ummat}

Berdirinya Partai Masyumi hasil Kongres Umat Islam Indonesia pada tanggal 7 November 1945 adalah sebagai sarana politik umat Islam untuk dapat menyalurkan aspirasi dan partisipasinya sebagai rakyat Islam Indonesia yang saat itu sedang semangat melaksanakan hidup berpolitik untuk mewujudkan negara yang demokrasi, pasca perang. Partai Masyumi hasil bentukan Kongres Umat Islam Indonesia ini diumumkan di Madrasah Muallimin Muhammadiyah Yogyakarta, satusatunya partai politik Islam di Indonesia yang memiliki keanggotaan selain perorangan juga organisasi sebagai anggota istimewa. Partai Masyumi 
bentukan Kongres Ummat Islam Indonesia ini dibentuk dan didirikan oleh ummat Islam tanpa campur tangan pihak luar. Partai Masyumi ini mendapat sambutan hangat dari hampir semua gerakan Islam nasional maupun lokal, politik maupun sosial keagamaan. Disebut Masyumi karena telah menyatukan sebagian potensi ummat Islam, mulai dari politisi, ulama, dan cendekiawan dalam berbagai organisasi Islam pada waktu itu, seperti Muhammadiyah, Persis, NU, Pergerakan Tarbiyah Islamiyah (Perti), dan PSII. Semua ini bersatu dalam satu partai walaupun pada akhirnya pecah dan ada yang mengundurkan diri hingga kemudian dibubarkan oleh Soekarno pada tahun 1960. Walaupun dalam sejarahnya adalah dipaksa membubarkan diri oleh Presiden Soekarno, pada akhir tahun 1960. Soekarno menerbitkan Keppres Nomor 200/1960 tanggal 15 Agustus 1960, yang isinya membubarkan Masyumi dan PSI (Partai Sosialis Indonesia). Namun pelaksanaan pembubaran itu harus dilakukan sendiri oleh Masyumi dan PSI. Jika dalam tempo seratus hari kedua partai itu tidak membubarkan diri, maka partai itu akan dinyatakan sebagai partai terlarang. Sebab itulah Ketua Umum Masyumi Prawoto Mangkusasmito dan Sekjennya Muhammad Yunan Nasution, mengeluarkan pernyataan politik membubarkan Masyumi, mulai dari pusat sampai ke daerah-daerah. ${ }^{6}$

$\begin{array}{ccc}\text { Partai } & \text { Masyumi } & \text { bertujuan } \\ \text { menegakkan } & \text { kalimah } & \text { Ilahi, }\end{array}$ terlaksananya ajaran-ajaran Islam dalam kehidupan orang perseorangan, masyarakat, dan negara. Mochammad Natsir sebagai ketua umum Partai Masyumi sangat komitmen terhadap ajaran Islam baik dalam perjuangannya di dunia politik, dakwah, dan bermasyarakat. Mochammad. Natsir

\footnotetext{
${ }^{6}$ Herbert Feith dan Lance Castles, ed., op. cit.
}

juga selalu menghimbau agar masyarakat selalu mengikuti perintah Al-Qur'an dan Hadits dan berlomba dalam berbuat kebajikan serta menyerahkan kepada Allah agar semua cita-cita dapat terwujud karena keridloan Ilahi. $^{7}$

Munculnya Partai Masyumi ini dapat pula dipandang sebagai jawaban positif ummat Islam terhadap manifesto politik Wakil Presiden Moehammad Hatta tertanggal 1 November 1945 yang mendorong pembentukan partai-partai. Pemimpin-pemimpin ummat Islam telah lama memanfaatkan kesempatan ini, dan Mochammad Natsir mempunyai komitmen yang sangat kuat terhadap Islam dan berbagai organisasi yang menjadikan Islam sebagai komitmen dalam perjuangannya. Seperti dalam anggaran dasar Partai Masyumi ditegaskan secara gamblang --seperti dikutip A. Syafii Ma'arif dari Pedoman Perjuangan Partai Masyumi-bahwa tujuan partai adalah terlaksananya ajaran dan hukum Islam di dalam kehidupan individu, masyarakat, dan negara Republik Indonesia menuju keridhaan Ilahi. Tujuan ini dijabarkan jelas dalam tafsiran anggaran dasar tentang gambaran suatu negara yang berdasarkan Islam,

"Kita menuju kepada baldatun thayyibatun wa Rabbun ghafur, negara yang berkebijakan dan diliputi ampunan Ilahi, di mana negara melakukan kekuasaannya atas musyawarah dengan perataraan wakil-wakil rakyat yang dipilih, di mana kaidah-kaidah kedaulatan rakyat, kemerdekaan, persamaan, tasamuh 'lapang dada', keadilan sosial sebagai yang diajarkan oleh Islam, terlaksana sepenuhnya, di mana kaum muslimin mendapat kesempatan untuk mengatur kehidupan pribadi dan masyarakat sesuai dengan ajaran dan hukum-hukum yang tercantum dalam Al-Qur'an dan As-

\footnotetext{
${ }^{7}$ Deliar Noer, Partai Islam..., op. cit., hal. 145-146
} 
Sunnah, di mana golongan keagamaan lainnya memilih kemerdekaan untuk menganut dan mengamalkan agamanya serta mengembangkan kebudayaan di mana seluruh penduduk dari segenap lapisan dapat hidup atas keragaman, terjamin baginya hak-hak azasi manusia, yang termasuk di dalamnya keadilan di lapangan sosial, ekonomi, dan politik, kemerdekaan berpikir dan mengeluarkan pendapat, di mana kemerdekaan menganut dan menjalankan agama satu dan lainnya tidak bertentangan dengan undang-undang negara dan susila." 8

Dalam perkembangan selanjutnya Partai Masyumi berhasil menarik jumlah pengikut yang besar, karena itu Partai Masyumi diharapkan tampil sebagai partai terkuat dalam pemilu nasional dan dengan basis yang kuat di pedesaan, masyarakat menginginkan pemilu cepat dilaksanakan sehingga mereka yakin meraih kemenangan dan akan membangun negara yang sejahtera. Mochammad Natsir memimpin Partai Masyumi sebagai ketua umum sejak 1949 sampai 1958, dua tahun sebelum dibubarkan dan selama sembilan tahun itu Mochammad Natsir memainkan peranannya dalam Partai Masyumi sebagai partai Islam terbesar dalam percaturan politik di Indonesia.

Sebagai pemimpin politik Islam, Mochammad Natsir secara maksimal telah memberikan seluruh tenaga dan pikirannya demi kepentingan ummat Islam di Indonesia dan seluruh bangsa Indonesia. Hal ini dapat dibuktikan melalui apa yang disebut "Mosi Integral M. Natsir" yang disampaikan dalam Sidang Dewan Perwakilan Rakyat/DPR RIS pada tanggal 3 April 1950. Mosi inilah yang mengantarkan masingmasing negara bagian bersatu kembali dalam Negara Kesatuan RI. Dari mosi

\footnotetext{
8 Thohir Luth, M. Natsir: Dakwah dan Pemikirannya, Jakarta, Gema Insani Press, 199, hal. 44
}

ini kemudian lahirlah proklamasi kedua yang dikumandangkan oleh Presiden Soekarno pada tanggal 17 Agustus 1950 di Istana Merdeka. Intinya, RI untuk kedua kalinya bersatu kembali dan diproklamasikan menjadi negara kesatuan. Mosi ini dibicarakan terlebih dahulu dalam Dewan Pimpinan Partai Masyumi, dan nilainya diakui secara umum sangat strategis bagi perjuangan perjalanan Republik Indonesia di masamasa yang akan datang, sebab dengan mosi ini Indonesia menjadi satu dan kokoh.

Selama Mohammad Natsir duduk di kabinet dari 6 September 1950 - Maret 1951, banyak program yang dicanangkan Kabinet Natsir ini, di antaranya adalah: menggiatkan usaha keamanan dan ketentraman; mencapai konsolidasi dan menyempurnakan susunan pemerintahan; menyempurnakan organisasi Angkatan Perang dan pemulihan bekas anggotaanggota tentara dan gerilya dalam masyarakat; memperjuangkan penyelesaian soal Irian secepatnya; mengembangkan dan memperkuat kekuatan ekonomi rakyat sebagai dasar bagi melaksanakan ekonomi nasional yang sehat. ${ }^{9}$ Hal ini sesuai dengan hasil Kongres Masyumi tahun 1952 yang mengemukakan tentang perjuangan Partai Masyumi dalam hidup bermasyarakat dan bernegara. Program ini terbagi ke dalam tujuh bagian, yaitu kenegaraan, perekonomian, keuangan, sosial, pendidikan dan kebudayaan, luar negeri, dan Irian Barat. Seperti rinciannya sebagai berikut:

1. Dalam pokus kenegaraan Masyumi memperjuangkan terbentuknya negara menurut hukum Islam dengan bentuk Republik. Negara hendaklah menjamin keselamatan jiwa dan benda tiap-tiap warga negaranya serta kebebasan beragama. Dasar politik Masyumi dalam hidup bernegara adalah mengembalikan 
kedudukan Undang-Undang, mengembalikan ketertiban hukum demokrasi, menjaga jangan sampai daerah-daerah melepaskan dirinya dari Negara Kesatuan Republik Indonesia, dan meyakinkan kepada seluruh warga negara bahwa kekerasan senjata tidak akan membawa penyelesaian. ${ }^{10}$

2. Masyumi juga memperjuangkan progarm perekonomian. Perekonomian hendaklah diatur menurut dasar ekonomi terpimpin, perencanaan produksi dan distribusi penting untuk kesejahteraan rakyat seluas-luasnya. Politik harga dan upah harus sesuai dengan keadaan ekonomi dalam negeri. Koperasi harus dibangun dengan bantuan pemerintah. Mengadakan industrialisasi untuk membebaskan Indonesia dari ketergantungan impor. Selain itu untuk membuka lapangan kerja terutama bagi para pengangguran asal daerah-daerah yang penduduknya padat. Pemerintah juga harus melindungi para petani dengan memberantas perilaku pemerasan terhadap mereka dan menghapuskan sistem tuan tanah, menjamin harga jual hasil pertanian bagi para petani, dsb. Karena sebagai warga negara Indonesia yang produksi utama di Indonesia adalah pertanian akan tetapi kebanyakan para petani bekerja sebagai buruh tani, sehingga tidak dapat menikmati kebahagiaan yang lebih besar dari hasil yang dikerjakannya maka Masyumi mengusulkan selain harus diadakan transmigrasi ke luar Jawa maka harus ada industrialisasi dari lapisan bawah dan atas. Industrialisasi dari bawah dengan menyuburkan dan memimpin kerajinan di rumah (cottage industry) dengan mempergunakan kerajinan-kerajinan yang ada sebagai dasar di samping dengan pembangunan koperasi-koperasi pruduksi dan penjualan. Mempertinggi nilai dan

${ }^{10}$ Lukman Hakiem, M. Natsir, PRRI, dan Masyumi, dalam 100 tahun Mohammad Natsir: Berdamai dengan Sejarah, Republika, Jakarta, 2008, hal. 290-291 efesiensi perusahaan rakyat yang sudah ada. Sedangkan industrialisai dari atas adalah dengan menambah perusahaanperusahaan menengah dan besar atau sekurang-kurangnya menghidupkan kembali perusahaan yang banyak membutuhkan tenaga kerja. Selain itu supaya para petani tidak konservatif, maka mekanisasi perlu dilakukan kepada bengkel-bengkel dan menambah sekolah-sekolah teknik dan montir. ${ }^{11} \mathrm{Di}$ bawah ini dapat terlihat dalam beberapa pokok penting program Masyumi dalam bidang ekonomi dan keuangan adalah:

a. Menghilangkan sebab yang pertama dari inflasi dengan menyusun Anggaran Belanja Negara yang sehat. Titik berat Anggaran Belanja diletakkan pada keamanan dan pendidikan atau pengajaran serta usaha-usaha produktif yang letaknya di lapangan "public utilities" (pengairan, listrik, dll). Usaha pemerintah harus diusahakan dengan penerimaan negara. Pajak sedapat mungkin diringankan.

b. Sejalan dengan penyehatan Anggaran Belanja, harus diadakan perubahan radikal dalam politik ekonomi, dari politik yang chauvinist nasionalistis, harus berpindah ke politik ekonomi baru, yang ditujukan untuk mempergunakan segala potensi yang ada dalam masyarakat dengan tidak memandang asal turunan, serta bantuanbantuan yang dapat didatangkan dari luar negeri, guna mencapai kemakmuran dengan menciptakan kesempatan bekerja yang seluas-luasnya.

c. Segala bantuan materiil baik dari pemerintah maupun dari badan-badan resmi dan setengah resmi kepada rakyat dan pengusaha-pengusaha nasional yang masih lemah harus langsung diberikan kepada yang berkepentingan. Bantuan yang tidak langsung seperti hak dan lisensi istimewa yang pada hakekatnya merugikan rakyat, harus segera

\footnotetext{
11 Surat Kabar Harian Abadi, Tahun ke-I, Tanggal 10 Nopember 1951
} 
dihapuskan, sehingga tidak membahayakan kedudukan Anggaran Belanja dan perkembangan moneter yang sehat. ${ }^{12}$

3. Dalam bidang keuangan Masyumi menganggap pentingnya undang-undang perbankan. Selain itu perkreditan dan perpajakan perlu pengawasan yang baik dan ketat dari pemerintah. Dalam RAB (Rencana Anggaran Belanja) pemerintah untuk tahun 1959, ${ }^{13}$ Masyumi mengingatkan supaya pemerintah kembali mengontrol program keuangan negara yang menyangkut dengan perekonomian dan kesejahteraan rakyat.

4. Program Masyumi selanjutnya adalah program sosial. Dalam program ini Masyumi perlu menyempurnakan Undang-Undang Perburuhan dengan memperhatikan jaminan sosial, seperti kecelakaan, hari tua, kesehatan, dsb. Buruh hendaknya memperoleh upah sosial di samping upah kerja temasuk di dalamnya tanggungan keluarga dan hari tua serta dua anak. Masyarakat perlu dibantu dalam membimbing anak-anak terlantar, pemberantasan perjudian, dan seks bebas. Masyumi melarang segala macam jenis perjudian, minuman kera, madat dan perzinahan, serta riba. Kaum buruh juga harus diberi kesempatan dalam melaksanakan beribadah sesuai syari'at Islam dalam waktu kerjanya. Masyumi memberi jaminan kepada para petani dalam hak memiliki sebidang tanah untuk jaminan hidupnya. Pembatasan hak milik seseorang dengan ketentuan agama Islam (pemberian zakat, qurban, dsb). ${ }^{14}$

5. Pendidikan dan Kebudayaan. Sekolahsekolah swasta agama perlu diberi subsidi. Pemberian pengetahuan agama

12 M. Natsir, Capita Selecta, Jilid 2, PT. Abadi dan Yayasan Capita Selecta, Jakarta, Cet. Ke-2, 2008, hal 246-247

${ }^{13}$ Surat Kabar Harian Abadi, No. 115, Tahun ke-VIII, 6 November 1958

${ }^{14}$ Deliar Noer, Partai Islam...., op. cit., hal. 127 perlu diberikan di sekolah-sekolah dalam pembentukan watak dan kepribadian sehingga anggota masyarakat menjadi bertanggung jawab dan berjiwa berani, berdisiplin, dan bersusila. Gerakan kebudayaan perlu dibimbing oleh pemerintah ke arah budi pekerti yang luhur. Dalam ulang tahun Masyumi ke-13 surat kabar Harian Abadi memuat tentang pembangunan kehidupan rakyat dan realisasi dari kemakmuran sebagai salah satu hal yang esensial. Dalam pembangunan kehidupan rakyat ini perlu adanya pemberantasan buta huruf dan buta hati sebagai hal yang utama dalam mengangkat derajat dan kecerdasan bangsa dalam pembangunan demokrasi. ${ }^{15}$

6. Dalam melaksanakan politik luar negeri Masyumi sangat menentang penjajahan. Politik luar negeri hendaklah mendukung dan mempertahankan perdamaian dunia dan mencari persahabatan dengan semua bangsa "terutama dengan bangsa yang berasaskan ketuhanan dan demokrasi". Negara-negara hendaklah saling menghormati hak masing-masing dan menjunjung tinggi perjanjian-perjanjian antanrbangsa. ${ }^{16}$ Dalam melaksanakan politik luar negeri, Masyumi bertujuan untuk mempererat tali persaudaraan antara ummat Islam Indonesia dan ummat Islam di negara-negara lain. Selain itu sebagai usaha supaya politik ummat Islam Indonesia dapat menempatkan Negara Republik Indonesia yang hidup berdapingan dengan negar-negara demokrasi lainnya. Menerima sikap pemberian lapangan hidup di Indonesia kepada siapa pun sepanjang tidak bertentangan dengan hukum negara dan tidak ditekan dengan senjata.. Masalah ideologi Islam penyebarannya dilakukan melalui

\footnotetext{
${ }^{15}$ Harian Abadi, No. 115, Tahun ke-VIII, 5 November 1958

${ }^{16}$ Deliar Noer, Partai Islam...., op. cit., hal. 151
} 
dakwah dan amal yang dapat menciptakan masyarakat Indonesia yang Islami, damai, dan tunduk kepada Allah. Melakukan hal itu berarti turut serta dalam menciptakan perdamaian dunia sebagai wujud dari politk luar negeri bangsa Indonesia. Hal ini menurut Mohammad Hatta ${ }^{17}$ karena Islam adalah agama yang mencintai perdamaian antara manusia dan masyarakat yang tidak mengikuti jejak iblis yang menggoda mengajak melakukan kejahatan dan perpecahan. Keadilan sosial adalah suatu bukti untuk mencapai keadilan Ilahi yang menjauhi perpecahan, permusuhan, dan pertentangan antara manusia. Kebijakan luar negeri seperti yang diterapkan Mohammad Natsir adalah bebas dan netral namun tetap bersimpati kepada negara-negara Barat. Pada bulan September 1950, Indonesia diterima menjadi anggota Perserikatan Bangsa Bangsa (PBB). Pemerintah Natsir menghadapi keadaan ekonomi yang paling menguntungkan selama demokrasi konstitusional, karena kenaikan harga komoditi sebagai akibat Perang Korea meningkatkan pendapatan ekspor dan bea ekspor pemerintah sampai pertengahan tahun 1951. Ketika para politisi di Jakarta mulai berebut keuntungan ekonomi, maka Menteri Keuangan dari Masyumi, Syafruddin Prawiranegara (1911-1989), dikecam karena menolak menggunakan pendapatan-pendapatan tersebut untuk memberikan keuntungan kepada mereka. Kebijakan Syafruddin sejalan dengan konsentrasi kabinet Natsir pada kebutuhan-kebutuhan pembangunan kembali perekonomian dan pemulihan keamanan. ${ }^{18}$

\footnotetext{
17 Mohamaad Hatta, "Islam dan Pembangunan Masyarakat" dalam Harian Abadi, No. 112, Tahun keVIII, 30 Oktober 1958, dan 8-11 November 1958

${ }^{18}$ M. C. Ricklefs, Sejarah Indonesia Modern 1200-2004, Serambi, Jakarta, 2001, hal. 481
}

7. Program ketujuh dalam kerja Masyumi adalah pembebasan Irian Barat dari kolonialisme Belanda. Irian Barat merupakan tuntutan nasional selama belum masuk wilayah Indonesia. ${ }^{19}$

Pemerintah saat itu dihadapkan pada ekonomi yang kritis, terutama karena jatuhnya harga barang-barang ekspor Indonesia seperti: karet, timah, beras, minyak, bensin, dan kopra. Sedang kecenderungan impor terus meningkat, karena produksi panen terus menurun sehingga defisit negara tidak dapat dihindarkan lagi. Beberapa pejabat negara melakukan korupsi, seperti Mr. Djodi Gondokusumo yaitu mantan menteri kehakiman dalam kabinet Ali I yang demisioner. $\mathrm{Mr}$ Djodi Gondokusumo ditangkap dengan tuduhan korupsi tersebut pada tanggal 14 Agustus 1955, masa Kabinet Burhanuddin Harahap. ${ }^{20}$

Dalam situasi politik yang masih mencari bentuk yang selaras dan bahkan idealis itu untuk mempertahankan kemerdekaan prioritas utama program kabinet pemerintahan adalah pada pemulihan ekonomi, meski dalam kenyataannya program tersebut sulit dilaksanakan. Dalam catatan sejarah bahwa masa Demokrasi Parlementer 1950-1957 pada dasarnya belum memiliki kemampuan untuk melaksanakan pembangunan ekonomi, langkah-langkah yang ditempuh hanyalah berupa rehabilitasi struktur perekonomian dan penanggulangan kesulitan keuangan. Seperti program Rencana Urgensi Perekonomian pada tahun 1951, program ini lebih kepada mengubah struktur ekonomi kolonial menjadi ekonomi nasional dengan prioritas pada industri kecil. Namun demikian rencana ini suatu gagasan yang mulia sebagai tindakan darurat

\footnotetext{
${ }^{19}$ Deliar Noer, Partai Islam...., op. cit., hal. 151

${ }^{20}$ Harian Abadi, No. 112-113, No. 115, dan No. 117 tahun ke-VIII, 1958, Perpustakaan Nasional, Jakarta
} 
dalam mengatasi kemerosotan ekonomi pasca perang. ${ }^{21}$

Masa Demokrasi Parlementer memang sudah diupayakan agar tercipta lapisan-lapisan pengusaha nasional agar dapat menjadi mitra pemerintah dalam membangun ekonomi nasional. Kebijakan ini dikenal dengan Kebijakan Benteng yang menekankan Indonesianisasi. Kemudian program ekonomi terus berlanjut pada masa Demokrasi Terpimpin 1958-1966, dengan melansir Rencana Juanda, yaitu suatu bangunan ekonomi Indonesia yang dilandaskan pada suatu pemikiran ekonomi yang disusun oleh Biro Perancang Negara yang memperhitungkan proyek-proyek investasi dalam perencanaan pembangunan. Gagasan industrialisasi yang bertujuan mengubah ekonomi kolonial menjadi ekonomi nasional pun direncanakan kembali. Akan tetapi rencana yang matang ini pun tidak dapat terlaksana sepenuhnya karena berbagai situasi politik yang terjadi saat itu.

Ketika terjadi penurunan di sektor pertanian pada masa itu serentak sangat mempengaruhi kesejahteraan masyarakat dan banyak memunculkan keresahan sosial di berbagai tempat. Kesulitan mendapatkan beras sebagai bahan pokok masyarakat Indonesia dirasakan di mana-mana, seperti di Aceh, Palembang, Padang, Sulawesi, Kalimantan, dan hampir seluruh Pulau Jawa. Hal ini karena harga beras yang mengalami kenaikan dari semula seharga Rp. 13,- menjadi Rp. 22,- per bambu. Keadaan seperti ini juga karena pemerintah banyak mengimpor beras dari Rusia dan Cina yang harganya lebih mahal. Seperti yang dijelaskan oleh Imam Sutardjo, anggota DPR dari partai buruh, bahwa pemerintah telah

${ }^{21}$ R.Z. Leirissa, et. al., Sejarah Perekonomian Indonesia, Proyek Inventarisasi dan Dokumentasi Sejarah Nasional, Departemen Pendidikan dan kebudayaan RI, Jakarta, 1996, hal. 93-98 mempersiapkan kontrak pembelian beras dari Rusia sejumlah 200.000 ton. $^{22}$ Sikap pemerintah yang banyak menaikan harga dalam sektor ekonomi seperti beras, bensin, kopra, kelapa sawit, dan sebagainya membuat rakyat semakin tidak percaya kepada pemerintah. Selain itu mempengaruhi pada pola hidup sehat masyarakat yang akibatnya banyak masyarakat yang menderita busung lapar, kekurangan vitamin A, dan penyakit kwashiorkor ${ }^{23}$ (penyakit kekurangan semua zat makanan terutama protein). Selain itu masyarakat jauh dari prilaku hidup bersih.

Untuk menghindari perilaku seperti itu, bahwa dalam hidup bernegara, landasan demokrasi yang tepat yang harus dipakai menurut Mohammad Natsir adalah Islam. Menurutnya Islam harus dijadikan sebagai dasar dalam membangun negara dan hidup bermasyarakat. Islam sangat berfungsi dalam memperjuangkan masyarakat yang demokratis, tentram, dan sejahtera. Begitu pentingnya peran agama dalam hidup bernegara dan bermasyarakat. Peran agama dan keberadaan Tuhan ini tidak bisa dilihat hanya pada penguasa melainkan juga rakyat untuk dapat mengerem dirinya dan lingkungannya dari tindakan merusak. Dengan keyakinan ini baik penguasa ataupun rakyat mampu menyampaikan kebenaran atau mengakkan amar ma'ruf nahyi munkar dan kritis. Inilah sebagai esensi demokratis. ${ }^{24}$ Dengan berpedoman pada

\footnotetext{
${ }^{22}$ Harian Abadi, No. 112-113, No. 115, dan No. 117 tahun ke-VIII, Oktober-November 1958, Koleksi Perpustakaan Nasional, Jakarta

${ }^{23}$ Penyakit-penyakit yang diakibatkan karena kekurangan makanan ini disamapaikan dalam pemberitaanpemberitan koran dan majalah sezaman oleh Prof. Dr. Poorwo Soedarmo, direktur Lembaga Makanan Rakyat, tahun 1958, yang bertempat di Djakarta, lihat Harian Abadi, No. 112, No. 115, tahun ke-VIII, 30 Oktober 1958, Koleksi Perpustakaan Nasional, Jakarta

${ }^{24}$ Lukman Hakiem, ed., op. cit., hal. 60
} 
agama dalam mengurus negara dan rakyat setidaknya sandiwara politik akan dapat ditekan semaksimal mungkin dan konflik yang terjadi antarlembaga ataupun antarpartai dapat diminimalisir. Mohammad Natsir mengkritik sistem sekularisme dan mempertentangkannya dengan ajaran Islam dan partai Masyumi yang dipimpinnya selalu menyerukan akan pentingnya ajaran Islam dalam membangun negara dan dalam bermasyarakat. Menyampaikan kebenaran atau dalam artian demokrasi berarti tidak boleh mengubah nilai moral yang diajarkan agama, seperti memelihara institusi keluarga, mencegah zina dan berbagai penyimpangan seksual, hormat kepada orang tua, toleransi dan menghormati ras, agama, dan suku, menghormati nyawa dan hak milik orang lain, serta pemerataan kesempatan berusaha dan menikmati hasil-hasil pembangunan.

Perjuangan Mohammad Natsir ini karena menginginkan masyarakat agar tidak terjerumus pada sekularisme yang dapat menghancurkan institusi keluarga, kecanduan obat-obatan terlarang, kosongnya nilai spiritual, besarnya jurang pemisah antara yang kaya dan yang miskin, serta merusak lingkungan hidup. Pemikiran seperti ini juga banyak diuraikan oleh Mohammad Hatta dalam surat kabar harian Abadi ${ }^{25}$ yang dimuat dalam beberapa terbitan dalam artikel yang berjudul "Islam dan Pembangunan Masyarakat". Pemikiran Mohammad Hatta sama dengan apa yang diperjuangkan Mohammad Natsir yang sangat memikirkan bagaimana masyarakat Islam memahami Islam tentang hidup bermasyarakat dan bagaimana mestinya membangun

\footnotetext{
${ }^{25}$ Mohammad Hatta, "Islam dan Pembangunan Masyarakat", artikel I-IV, Harian Abadi, No. 112-128, tahun ke- VIII, 1958, Koleksi Perpustakaan Nasional, Jakarta
}

masyarakat menurut Islam. Berikut beberapa kutipan dari tulisan Mohammad Hatta dalam surat kabar harian Abadi:

...Islam menghendaki damai. Kita satu sama lain harus kasih sayang seperti dijelaskan dalam Al-Qur'an surat AlBaqoroh ayat 214. Mari kita susun corak masyarakat Islam yang melaksanakan kehendak Ilahi yang setingi-tingginya. ...Keadilan sosial, untuk mencapai keadilan Ilahi. (Harian Abadi, "Islam dan Pembangunan Masyarakat", tahun ke-VIII, 8 November 1958)

...Mengutip hadits Nabi: "aturlah hidupmu sedemikian rupa seolah-olah kamu akan mati esok hari, tetapi juga seolah-olah kamu akan hidup selamanya"....Kita harus perbaiki diri untuk persiapan akhirat kita. Kita harus perbaiki bumi Allah supaya tercapai keadilan Ilahi. Islam tidak memandang kelas. Islam tidak memandang si kaya dan si miskin. Berilah sebagian rezeki untuk pengemis, rezeki esok hari Tuhan yang mengatur. Inilah Islam mendidik sosialisme bukan dari Marx, tapi sosialisme yang datang dari Tuhan. Di mesjid tidak ada raja tidak ada bupati. Inilah demokrasi. Haruslah dipraktekan keadilan Ilahi di atas dunia dimana orang tidak ada yang kekurangan, dan takut-takut. Masyarakat harus diciptakan dalam suasana yang harmonis, yang baik, dimana dapat persamaan dan persaudaraan antara manusia dan bangsa berdasarkan kebersamaan dan keadilan. Seperti dalam Mukadimah UUD kita: mewujudkan kebahagiaan, kesejahteraan, perdamaian, dan kemerdekaan. ...Jauhi permusuhan, pencederaan, dan pertengkaran. Jauhi individualisme yang memusatkan kemerdekaan orang perseorangan. (Harian Abadi, "Islam dan Pembangunan Masyarakat", tahun keVIII, 10 November 1958)

...Islam dan pembangunan masyarakat bukanlah suatu masalah yang kecil tapi 
sangat luas. Kita harus mencari titik berat, jiwa apakah yang diberikan Islam untuk pembangunan masyarakat kita. ...Kita membangun kalau kita berkekeluargaan yang mengutamakan kasih sayang dan menggunakan keadilan Ilahi. ...Kita harus bisa merasakan keadilan Ilahi, tidak ada orang yang merasa takut, tapi harmonis damai di Indonesia ini sesuai dengan ajaran Islam....Dengan ilmu tentang masyarakat pemimpin kita harus tahu ke mana masyarakat yang semakin berkembang ini dibawa, jangan sudah kaya hilang keisyafannya terhadap masyarakat yang masih buruk. Begitu juga kaum melarat sebaiknya selalu memikirkan bagaimana mau berubah seperti sudah dijelaskan dalam AlQur'an surat Ali Imran. (Harian Abadi, "Mari Menyusun Masyarakat Berdasar Islam, Islam adalah Damai, Tidak Mengikuti Jejak Iblis",No. 112, tahun ke-VIII, 30 November 1958)

Karena bangsa kita bangsa yang berbineka, menurut Mochammad Natsir bahwa dalam hidup bernegara kita harus demokrasi yaitu mengutamakan kepentingan rakyat, rakyat sebagai pemegang kekuasaan tertinggi dengan tetap menjalankan kepatuhan terhadap ajaran agama bukan berarti menyingkirkannya. Konsep ini yang kemudian Ir. Soekarno menilai demokrasi Barat tidak sama dengan demokrasi Indonesia. ${ }^{26}$ Dalam rangka mencari bentuk dan sifat demokrasi yang sesuai dengan masyarakat Indonesia, Mohammad Hatta menyetujui sistem musyawarah karena musyawarah menolak cara-cara untuk menang sendiri, sikap otoriter, dan diktatorial. Menurut Hatta, sifat musyawarah dalam tradisi Indonesia perlu diterapkan dalam badan-badan perwakilan, dan ini yang

\footnotetext{
${ }^{26}$ Harian Abadi, tahun ke-VI, 30 Oktober 1956, Duta Masyarakat, 29 dan 30 Okteber 1956, dan Merdeka, 30 Oktober 1956, Koleksi Perpustakaan Nasional, Jakarta
}

membedakan demokrasi Indonesia dengan demokrasi Barat yang individualistis. ${ }^{27}$ Begitu juga menurut Mohammad Natsir, karena bangsa kita bangsa yang suka tolong menolong maka sangat tepat apabila negara kita negara demokrasi yang tidak mengesampingkan ajaran-ajaran agama dan mengutamakan kepentingan rakyat. Dalam Islam mengajarkan tolong menolong, seperti yang dijelaskan dalam Al-Qur'an bahwa "bertolong-tolonglah kamu dalam kebajikan dan dalam berbakti kepada Tuhan dan jangan bertolong-tolong atas dosa dan bermusuhan". Mohammad Natsir menegaskan bahwa dalam Islam, nilai musyawarah diatur dalam hidup bermasyarakat dan bernegara, karena seorang penguasa dalam mengatur kehidupan orang banyak harus mendapat keridhaan dari orang yang diaturnya dan harus memusyawarahkan segala sesuatu yang mengenai perikehidupan dan kepentingan rakyat banyak. Peraturan yang tegas dalam Al-Qur'an tentang musyawarah ini dijelaskan, dengan bunyi ayat "wasyawirhum fil amri" yaitu "bermusyawarahlah kamu dengan mereka di dalam urusan yang mengenai diri mereka". ${ }^{28}$ Menurut Mochammad natsir bahwa demokrasi yang sejati adalah yang menjamin kebutuhan rakyat, demikian disampaikan dalam peringatan ulang tahun Masyumi yang ke-13, seperti dimuat dalam surat kabar harian Abadi tentang makna demokrasi sejati, yaitu bahwa:

Demokrasi dapat dibagi dalam dua bagian: pertama, demokrasi politik, yang menjamin kemerdekaan berpikir, berbicara, berserikat, beragama, dan keadilan sosial bagi seluruh rakyat. Kedua, demokrasi ekonomi, yang

\footnotetext{
Deliar Noer, Mohammad Hatta: Biografi Politik, LP3ES, Jakarta, 1990, hal. 494

${ }^{28}$ M. Natsir, Capita Selecta, Jilid 3, PT. Abadi, Jakarta 2008, hal. 124-128
} 
menjamin demokrasi ekonomi yang mencukupi kebutuhan masyarakat, baik sandang, pangan, papan. Itulah demokrasi sejati. (Harian Abadi, "Islam dan Pembangunan Masyarakat", tahun ke-VIII, No. 115, 5 Oktober 1958)

Penjelasan tentang makna demokrasi ini, dalam surat kabar harian Abadi tersebut menunjukkan adanya hubungan yang harmonis dan damai antara negara dan masyarakat yang berarti saling mewujudkan cita-cita dan tujuan berdirinya negara yang merdeka. Menurut Mochammad Natsir, negara yang merdeka adalah negara yang dapat membangkitkan kemauan dan kemampuannya untuk membela yang lemah dan membebaskan dari ketertindasan sehingga dapat merasakan bersama-sama keadilan, kemakmuran, dan kesejahteraan hidup. Ketertinggalan pembangunan di sebagian wilayah di Indonesia adalah suatu kenyataan, dari masa awal kemerdekaan sampai sekarang, pembangunan terutama sektor ekonomi dan pendidikan belum merata ke seluruh pelosok nusantara. Terlebih di wilayah tertinggal, daya beli masyarakat rendah, sumber daya manusia unskilled, dan sentuhan teknologi hanya sekedarnya. Tetapi ini adalah proses bagaimana solusi terbaik untuk mencapai kehidupan masyarakat yang sejahtera.

Kemiskinan, sebagai suatu kondisi ketika rendahnya tingkat pendapatan dan sumber daya produktif yang menjamin kehidupan yang berkesinambungan, kelaparan dan kekurangan gizi, rendahnya tingkat kesehatan, keterbatasan dan kurangnya akses kepada pendidikan dan layanan pokok lainnya, kondisi yang tak wajar dan kematian akibat penyakit yang terus meningkat, kehidupan bergelandang dan tempat tinggal yang tidak memadai, lingkungan yang tidak aman, serta diskrimansi dan keterasingan sosial, menjadi sebuah kenyataan juga yang tidak aneh lagi di Indonesia.

Memang pemerintah dari masa ke masa selalu berupaya untuk membebaskan dari kondisi kemiskinan tersebut, namun sebenarnya di luar itu terdapat potensi untuk bersama membantu, mengangkat, dan mengatasi permasalahan ini, yaitu dari diri kita sendiri. Pada dasarnya sikap yang dermawan dan relawan yang besar, seperti dari perusahaan-perusahaan maupun perorangan berperan dalam pembangunan ekonomi rakyat.

Sebagaimana Mohammad Hatta pernah menjelaskan tentang bagaimana mengatasi permasalahan masyarakat yang harus dimulai dari diri kita sendiri sebagai ummat yang beragama, ini dijelaskan dalam ceramahnya ${ }^{29}$ bahwa:

...Ummat Islam harus mengetahui kekuatan jiwanya sendiri sebagai ummat yang beradab. Dalam membangun masyarakat Islam telah memberi petunjuk berupa tuntunan dalam AlQur'an hanya ummat Islam saja yang tidak menyusun konsepsi untuk melaksanakan petunjuk-petunjuk tersebut. Mari kita susun masyarakat Islam sesuaikan dengan ajaran AlQur'an tersebut seperti ringkasnya dalam uraian inti ummul qur'an yaitu surat Al-Fatihah dan al-Baqoroh. Islam bukan sabar saja, ulama jangan hanya mementingkan masalah agama dan kurang mementingkan masalah masyarakat.

...Kita perlu kembangkan pandangan tentang masyarakat dan kemasyarakatan Islam atau ideologi Islam tentang masyarakat seperti, sosiologi, ekonomi, dan hukum, dsb.

\footnotetext{
${ }^{29}$ Ceramah ini diadakan oleh badan kontak organisasi Islam Djakarta Raya di GOR tanggal 1 November 1958 dan dihadiri Ny. Hatta, anggota parlemen dan Konstituante, serta para pembesar. Lihat surat kabar Harian Abadi, Tahun ke-VIII, Tanggal 5 dan 6 November 1958
} 
...Mari menyususn Masyarakat berdasarkan Islam karena Islam adalah berarti damai, tidak mengikuti jejak iblis. Islam dan pembangunan masyarakat bukanlah suatu masalah yang kecil tapi sangat luas. Kita harus mencari titik berat. Jiwa apakah yang diberikan Islam untuk pembangunan kita.

Demikian Islam mengakui kebebasan berideologi, kebebasan berpikir, kebebasan dari kemiskinan, dan kebebasan dari rasa takut. Islam mengakui, bahkan mendorong, upaya membebaskan manusia dari kemiskinan. Buktinya Islam mewajibkan zakat dan menekankan sedekah yang hasilnya diberikan kepada orang-orang fakir, orang-orang miskin, mereka yang sedang dalam perjalanan dan memerlukan bantuan, serta orang-orang susah lainnya. Al-Qur'an menganggap bahwa dalam harta orang-orang kaya terdapat hak tertentu bagi orang peminta-minta dan orang susah.

Seringkali kemiskinan dapat membunuh bakat dan potensi-potensi manusia, padahal betapa berharganya semua itu bagi kehidupan intelektual dan spiritual manusia, karena dapat mendatangkan kebajikan yang melimpah. Menurut Mochammad Natsir, kalau para ekonom meneriakkan keluhan lantaran kemiskinan materi, dunia sebenarnya mengeluh juga tentang kemiskinan spiritual. $\mathrm{Di}$ dalam kehidupannya, manusia memang seharusnya tunduk pada nilai-nilai moral yang akan membebaskannya dari kemiskinan spiritual itu. Hal ini karena dalam mendamaikan setiap perselisihan yang terjadi di antara mereka, dalam kehidupan internasional atau kehidupan nasional, nilai-nilai moral tetap harus dipegang. Antara kebutuhan materi dan kebutuhan spiritual hendaknya dipenuhi secara seimbang untuk mencapai kehidupan yang sempurna.
Menurut Mochammad Natsir, bahwa pembahasan Islam sangat menyeluruh tidak saja masalah agama, tetapi juga sosial, negara, politik, dan ekonomi. Islam masuk ke Indonesia dapat mempersatukan ideologi dan kekuatan politik melawan kolonialisme. Bagi para pemeluk agama Islam, Islam bukan sekedar agama sebagai tuntunan hidup, melainkan dapat memberikan pengaruh psikologis dan sosial yang tinggi yang dapat menciptakan solidaritas (ukhuwah) yang tinggi di antara pemeluknya. Mochammad Natsir, menggagas konsep dakwah Islam bukan sekedar menyampaikan ajaran Islam, tetapi amar ma'ruf nahi munkar yang di dalamnya mengandung tiga unsur utama yaitu amal perbuata lisan, aktualisasi ajaran Islam dengan karya nyata, dan kepribadian yang terpuji sebagai sokogurunya. Pemahaman konsep dakwah ini mempunyai implikasi terhadap perubahan masyarakat, baik dari sosiokuturalnya maupun geopolitiknya. Dalam konteks ini, tugas dakwah Islam itu lebih diarahkan sebagai kewajiban pribadi, bukan sebagai kewajiban kolektif. Artinya, semua orang harus berdakwah untuk dirinya, keluarganya, dan masyarakat di mana saja dan kapan saja, supaya dapat memacu adanya 'perubahan'. ${ }^{30}$

Mochammad. Natsir tampak tegas mengingatkan ummat Islam untuk melaksanakan ajaran-ajaran Islam, mengajak bertauhid, shalat, dan lain-lain dengan satu muara, yaitu ingin menjadikan masyarakat Islam yang mengamalkan ajaran Islam dalam segi kehidupan baik berbangsa maupun bernegara. Keberadaan Mochammad Natsir dalam Partai Masyumi telah membawa nuansa baru bagi perjuangan ummat Islam Indonesia terhadap kepentingan politik, ekonomi, dan sosial. Mochammad. Natsir selalu

\footnotetext{
${ }^{30}$ Thohir Luth, op. cit., hal. 41-52
} 
mengingatkan kepada rakyat Indonesia pada umumnya halnya dengan perjuangan hidup di dunia yang harus seimbang antara memenuhi kebutuhan materi untuk kehidupan di dunia dan mempelajari serta mengamalkan ajaran agama Islam sebagai tugas utama khalifah di bumi untuk mencapai kebahagiaan di akhirat.

Selama menjabat di kabinet, Mochammad Natsir, selalu memperhatikan perkembangan dan pembangunan ekonomi, dan ini dicurahkan oleh Sumitro Djojohadikusumo, yang menjabat sebagai menteri perdagangan pada masa itu (September 1950-April 1951). Menurut Sumitro bahwa pembangunan ekonomi Indonesia pada hakekatnya adalah membangun ekonomi baru. Menurutnya yang perlu dilakukan adalah mengubah struktur ekonomi umumnya dari ekonomi kolonial ke ekonomi nasional. Menurutnya bahwa di Indonesia harus ditumbuhkan kelas pengusaha. Para pengusaha di Indonesia umumnya bermodal lemah, maka harus diberi kesempatan untuk berpartisipasi membangun ekonomi nasional. Apabila usaha ini berhasil secara bertahap pengusaha bangsa Indonesia akan dapat berkembang maju dan tujuan mengubah ekonomi kolonial di bidang perdagangan akan tercapai. Dalam Kabinet Mochammad Natsir ini salah satu programnya di bidang pembangunan ekonomi adalah: "memperkembangkan dan memperkokoh kekuatan ekonomi rakyat sebagai dasar melaksanakan ekonomi nasional yang sehat". ${ }^{31}$

Program ini terkenal dengan sebutan Program Benteng. Gerakan Benteng (Benteng Group) telah dimulai pada bulan April 1950. Selama tiga

\footnotetext{
${ }^{31}$ Marwati Djoened Poesponegoro dan Nugroho Notosusanto, Sejarah Nasional Indonesia, Jilid VI, Balai Pustaka, Jakarta, 1984, hal. 240-241, lihat Harian Abadi, Tahun ke-III, 1953, lihat juga Berita Masyumi, Tahun 1951-1952
}

tahun (1950-1953) lebih kurang perusahaan bangsa Indonesia mendapat bantuan kredit dari Program Benteng ini. Program ini pada hakekatnya adalah kebijaksanaan untuk melindungi usahausaha pribumi, akan tetapi sayangnya program ini tidak tercapai seutuhnya karena para pengusaha Indonesia ternyata lamban dalam merealisasikan program tersebut bahkan ada yang menyalahgunakan program ini dengan mencari keuntungan untuk dirinya sendiri secara cepat. Bantuan kredit dari pemerintah ternyata tidak efektif padahal pemerintah sudah menambah beban keuangannya, akhirnya program ini menjadi salah satu sebab defisit negara. Krisis ini kemudian ditempuh usaha jalan ke luarnya pada masa Kabinet Sukiman yang memegang pemerintahan selama 10 bulan sejak April 1951-Februari 1952. Kabinet Sukiman berusaha membatasi krisis moneter ini yang defisit pada anggaran belanja sebanyak tiga milyar rupiah ditambah dengan defisit anggaran tahun sebelumnya sebesar 1,7 milyar rupiah. Kabinet Sukiman melakukan nasionalisasi Javasche Bank. ${ }^{32}$

Situasi perekonomian saat itu memang dikatakan Mochammad. Natsir sebagai situasi ekonomi yang genting sebagai imbas dari situasi ekonomi yang buruk juga di seluruh dunia. Tahun 1954 Amerika Serikat mengalami "resessi" atau "depresi" atau disebut rolling reajustment. Situasi perekonomian di Amerika Serikat tahun itu sangat mempengaruhi keadaan ekonomi Indonesia juga. Sehingga harga barangbarang ekspor dari Indonesia tidak menunjukkan angka kenaikan. Indonesia mengalami devisa sekitar 1 milyar rupiah bahkan dalam catatan Bank Indonesia tahun 1954, Indonesia

\footnotetext{
${ }^{32}$ Marwati Djoened Poesponegoro dan Nugroho Notosusanto, op. cit., hal. 240-241, lihat Harian Abadi, Tahun ke-III, 1953, lihat juga Berita Masyumi, Tahun 1951-1952
} 
berhutang sekitar 1,8 milyard rupiah. Industri dalam negeri yang tergantung dari impor barang-barang luar negeri menjadi lumpuh, sehingga barangbarang di pasar baik yang berasal dari impor atau hasil produksi dalam negeri terus membumbung harganya. ${ }^{33}$

Surat Kabar Harian Abadi dari tahun 1950-an banyak menyoroti tentang krisis ekonomi di hampir seluruh wilayah di Indonesia. Seperti di daerah Aceh secara merata masyarakat mengalami kesulitan beras karena kenaikan harga beras yang sangat drastis, akibatnya masyarakat Aceh mengganti jagung dan sagu sebagai makanan pokok sehari-hari, beras pemerintah saja yang semula seharga Rp.13,- dijual ke pasar oleh rakyat menjadi Rp.22,- per bambu. ${ }^{34}$ Selain di Aceh, di Padang dan di Jawa mengalami kenaikan beras. Kenaikan harga beras ini menjadi beban yang sangat berat bagi seluruh rakyat Indonesia. Kenaikan beras yang menjadi bahan pokok rakyat Indonesia ini mempengaruhi harga barang-barang lainnya.

Seperti kenaikan harga bensin, yang membuat masyarakat sering mengalami antrian yang panjang di POM bensin karena kesulitan mendapatkan bensin sebagai bahan bakar kendaraan bermotor. Di Medan, Palembang, Bandung, Sulawesi, Maluku, dan Nusa Tenggara, masyarakat mengalami kesulitan untuk mendapatkan bensin karena di setiap 'pompa minyak', sebutan untuk POM bensin pada tahun 1950-an, mengalami kekeringan bensin terutama pompapompa minyak yang disediakan untuk kendaraan umum yang tidak sama dengan pompa-pompa minyak yang disediakan untuk jawatan-jawatan atau

\footnotetext{
${ }^{33}$ Lihat di M. Natsir, Capita Selecta, Jilid 3, op. cit., 401407, lihat juga Surat Kabar Harian Abadi, Tahun ke-IV, 19 Februari 1954

${ }^{34}$ Surat Kabar Harian Abadi, Tahun ke-VIII, Tanggal 25-27 Oktober 1958
}

untuk perusahaan-perusahaan umum. Ketika bensin didapatkan pun harganya melebihi harga beras, yaitu sekitar Rp.17,50,- per liter. Panglima TT.I Letkol Djamin Gintings, sangat prihatin atas kasus ini, menurutnya pernah mendengar bahwa minyak PT. Pertamina dinaikkan harganya. Setiap motor terpaksa antri berjam-jam di depan pompa minyak. Keterangan diberikan oleh panglima untuk menjawab sampai di mana keberadaan informasi PT. Minyak Pertamina menaikkan harganya. Diduga dinaikkan oleh pompa-pompa minyak karena minyak bensin keluaran Stanvac dan BPM sulit diperoleh, selain itu banyak pula yang melakukan penimbunan minyak-minyak oleh tangan-tangan nakal. ${ }^{35}$

Selain itu karena kenaikan beras ini mempengaruhi terhadap kesulitan pengangkutan pada barangbarang pokok hasil produksi masingmasing daerah di Indonesia, seperti kopra dan sawit di Sulawesi, Maluku, dan Kalimantan Barat serta karet di Irian, dsb. Kesulitan yang dihadapi oleh daerah penghasil kopra adalah selain pelajaran pantai dan inter-insuler juga karena bahan bakar minyaknya yang mengalami kenaikan. Seperti di Sulawesi 109 tempat, Maluku 86 tempat, Nusatenggara 3 tempat. Luas itu lebih dari $1 / 2$ luas perairan Indonesia. Dari tempat itu kopra diangkut di tempat-tempat penumpukkan yang dapat disinggahi oleh kapal besar (interinsuler) kemudian diteruskan ke pasar dalam negeri dan luar negeri. Rakyat berteriak agar kopra segera diangkut. ${ }^{36}$ Padahal para pemuda dan rakyat di Sulawesi Utara Tengah telah berhasil membantu pemerintah dalam merebut wilayah penghasil kopra, sekitar $87 \%$, dari

\footnotetext{
${ }^{35}$ Surat Kabar Harian Abadi, Tahun ke-VIII, Tanggal 56 November 1958

${ }^{36}$ Surat Kabar Harian Abadi, Tahun ke-VIII, Tanggal 5 November 1958
} 
kaum pemberontak seperti PRRI/Permesta, Harian Abadi mencatat data statistik daerah penghasil kopra yang berhasil diambil alih lagi pemerintah Indonesia, dari catatan Antara pada tahun 1958, bahwa hanya tinggal $12,7 \%$ daerah-daerah penghasil kopra yang belum berhasil diambil alih kembali oleh pemerintah Indonesia dari kekuasaan kaum pemberontak tersebut. $^{37}$ Para pemuda dan rakyat Sulawesi Utara Tengah ini berusaha untuk memulihkan kembali situasi yang menegangkan akibat adanya pemberontak-pemberontak tersebut. Mereka merasa bahwa penghasilan dari kopra inilah yang dapat menopang hidup mereka. Sehingga mereka senantiasa memperjuangkan wilayahnya dari gangguan apa pun. Dari data statistik Induk Koperasi Kopra Indonesia (IKKI) pada tahun 1958, bahwa seluruh daerah Sulawesi Utara Tengah itu menghasilkan kopra dengan kualitas yang baik sekitar 875 ton kopra. Rincian ini sebagai berikut:

Menurut statistik Induk Kopersi Kopra (IKKI) seluruh daerah Sulawesi Utara Tengah menghasilkan 875 ton kopra dengan rincian Sangir-Talaud 2,56 ton, Bolangasoagosdow 2,150 ton, Gorontalo 3.350 ton, Donggala 1,750 ton dan poso 5,125 ton. Daerah Bolangasoagosdow belum sepenuhnya dikuasai pemerintah dan empat tempat di Minahasa yaitu Poigor 200 ton, Belang 300 ton, Bentenan 200 ton dan Bocatolak 200 ton. $^{38}$

Dengan perjuangan rakyat Sulawesi tersebut harusnya pemerintah memperhatikan kebutuhan rakyat Sulawesi dan atau seluruh rakyat Indonesia. Betapa kenaikan harga beras itu banyak mempengaruhi terhadap kenaikan barang-barang lainnya. Bahkan

\footnotetext{
${ }^{37}$ Surat Kabar Harian Abadi, Tahun ke-VIII, Tanggal 6 November 1958

${ }^{38}$ Surat Kabar Harian Abadi, Tahun ke-VIII, Tanggal 5 November 1958
}

selain Masyumi, juga PNI (Ny. Sumarni) dan Sumardi serta Siau Giok Tjhan (Nasional Progresifo), Moh. Noor AG (NU), dsb, Mohammad Sondakh (Parkindo), RG. Daerijat (Katolik), Lie Po Joe (PNI), Nunung Kusnadi (PSII), Run Tururambi (Pembangunan) dan Anwar Kadir (PKI), mengusulkan resolusi kenaikan beras. Menurutnya kenaikan harga beras sudah menjadi persoalan hangat di setiap wilayah di Indonesia. Partai Masyumi (Nurdin Harun), PSII (Abdul Rasyid) dan PSI (T. A. Murad) mengusulkan resolusi surat menteri perdagangan tentang kenaikan beras karena akan diikuti harga-harga barang lainnya. ${ }^{39}$ Pada tahun 1950 -an ini kemudian soal harga beras diajukan ke parlemen dan menjadi pembahasan serius dalam pemerintahan. Hal ini karena kenaikan beras dapat mempengaruhi harga barang-barang lainnya, maka hendaknya ditinjau kembali.

Kenaikan barang pokok, yaitu beras juga akan membuat rakyat hidup sengsara karena tidak mampu membelinya lagi, dan hal ini membuat rakyat akan jauh dari hidup sehat, padahal kesehatan juga termasuk hal yang utama dalam kehidupan. Dalam masalah kesehatan juga Mochammad Natsir berpandangan bahwa dalam ajaran agama Islam manusia hidup bertujuan untuk memelihara lima hal pokok yaitu; agama, jiwa akal, kehormatan (keturunan), dan kesehatan gizi yang dalam hal ini mempunyai peran sangat besar dalam membina dan mempertahankan kesehatan seseorang. Perilaku hidup sehat adalah merupakan kewajiban setiap orang dalam memelihara kesehatannya, seperti yang terungkap dalam sabda Nabi Muhammad saw., "sesungguhnya badanmu mempunyai hak atas dirimu" yang artinya adalah merupakan

\footnotetext{
${ }^{39}$ Surat Kabar Harian Abadi, Tahun ke-VIII, No. 113, Tanggal 30 Okober 1958
} 
kewajiban seseorang untuk memelihara jasmaninya, sehingga dapat berfungsi sebagaimana mestinya.

Selain itu Islam juga mengajarkan agar ummat Islam selalu memperhatikan makanannya, AlQur'an secara khusus menggambarkan bahwa manusia harus memilih makananmakanan yang bersifat nabati, berdasarkan konteksnya yang berbicara tentang hujan, biji-bijian, sayur-mayur, buah-buahan, dan rerumputan. Kemudian untuk dijadikan makanan yang halal lagi baik untuk kesehatan hidup manusia.

Pola hidup sehat dan bersih ini selalu didakwahkan oleh Mochammad Natsir sebagai pelaksanaan dari ajaran Islam. Islam mengajarkan kebersihan tidak hanya ketika hendak beribadah melainkan selalu bersih lingkungan dan makanan. Surat kabar Harian Abadi memuat pula tentang perilaku hidup sehat dan bersih sesuai dengan ajaran Islam bahwa "kebersihan itu sebagian dari iman". Ketua PBNU, KH.M. Dachlan, memahami jiwa masyarakat Indonesia yang sebagian besar beragama Islam, sehingga anjuran pola hidup sehat itu adalah yang sesuai dengan ajaran Islam. $^{40}$ Bahkan dalam surat kabar Harian Abadi setiap menyambut ulang tahun Masyumi selalu memuat artikel tentang pola hidup yang bersih, sehat, bermoral, berpendidikan, dan beragama. Menurut Harian Abadi ini bahwa dalam melaksanakan pembangunan rakyat itu harus melaksanakan seluruh sendi kehidupannya, dari mulai perilaku hidup sehari-hari sampai perilaku berpolitik. Pembangunan kehidupan rakyat dan realisasi dari kemakmuran untuk segenap rakyat Indonesia adalah menjadi suatu hal yang esensial bagi kemerdekaan suatu bangsa. Tidak hanya keamanan lahir saja yang menjadi syarat mutlak pembangunan negara melainkan

\footnotetext{
${ }^{40}$ Surat Kabar Harian Abadi, Tahun ke-VIII, Tanggal 30 Oktober 1958
}

pengetahuan lahir dan batin atau pengetahuan beragama dan cara hidup, juga menjadi hal yang utama.

Pemberantasan buta huruf dan buta hati adalah hal yang utama dalam mengangkat derajat dan martabat bangsa. Dengan kata lain bahwa menurut Presiden Soekarno, dalam memberikan kuliah di UNHAS (Universitas Hasanuddin) Makasar, bahwa pendidikan yang dibutuhkan itu adalah pendidikan tentang bagaimana cara mengabdi kepada masyarakat, menghasilkan ide-ide yang dapat dinikmati oleh masyarakat dan bagaimana berguru yang baik agar pendidikan yang didapat dapat berguna bagi masyarakat. ${ }^{41}$

Dengan membangun masyarakat yang cerdas dan bermartabat maka tugas kita sebagai ummat Islam dalam menegakkan dan menyelamatkan bangsa akan lebih bermanfaat dan dapat dirasakan langsung oleh seluruh rakyat Indonesia. Ini akan sesuai dengan tujuan yang diformulasikan dalam AD/ART Masyumi saat Masyumi didirikan sebagai partai politik, yaitu “...Masyumi bertujuan menegakkan Republik Indonesia dan agama Islam" dan ini bagi seorang Masyumi harus istiqomah atau konsisten dalam menegakkan tujuan ini. $^{42}$

Selaras dengan ini, dalam pemikiran Mochammad Natsir, bahwa Allah telah menganugerahkan kepada manusia dua jenis buku yang harus kita

\footnotetext{
${ }^{41}$ Setiap memperingati hari ulang tahun Masyumi, tanggal 7 November, Surat Kabar Harian Abadi ini selalu menulis dalam bagian 'Tajuk Rencana' di halaman pertama, tentang tugas manusia sebagai khalifah di bumi dan merupakan seruan bagi anggota Masyumi untuk selalu mengisi hidup dan kehidupannya yang berguna bagi masyarakat dan negara sesuai dengan ajaran Islam. Semua aktivitas Masyumi dalam menegakkan dan menyelamatkan negara dan bangsa atau sebagai partai politik Islam harus berguna untuk kebangkitan dan keselamatan agama, bangsa, dan tanah air. Surat Kabar Harian Abadi, Tahun 1950-1960

${ }^{42}$ Lihat di M. Natsir, Capita Selecta, Jilid 3, op. cit., lihat juga Surat Kabar Harian Abadi,
} 
baca (iqro') dan kita pahami. Buku pertama adalah kitab suci yang harus dibaca dan dipelajari karena sarat dengan pesan Ilahiyah yang harus dipahami dan diamalkan. Buku kedua adalah alam semesta, sebagaimana buku pertama, juga harus dibaca, dipelajari, dan dipahami sebaik-baiknya oleh manusia karena mengandung semua hal yang diperlukan untuk dapat survive. Hal ini yang harus dipelajari dengan cermat, karena bumi sesungguhnya menyediakan semua sarana yang diperlukan manusia untuk memenuhi kebutuhan pangannya. Dengan demikian seharusnya manusia mengoptimalkan dirinya dalam memahami kedua anugerah dari Allah ini. Pemerintah juga perlu memberdayakan masyarakatnya agar dapat mengolah bumi dan hasilnya untuk dapat dinikmati dalam kehidupan sehingga tidak terpuruk dalam kebodohan, kemiskinan, dan jauh dari hidup sehat. Ekonomi rakyat akan tumbuh dan menghasilkan produk yang bercita ekonomis dan bergizi, sehingga tidak hanya pada bidang ekonomi tetapi peningkatan mutu kesehatan.

Sejak tahun 1951 memang perkembangan ekonomi Indonesia tidak menunjukkan arah yang stabil. Pengeluaran pemerintah yang semakin meningkat akibat tidak stabilnya situasi politik, menjadi penyebab defisit negara. Pemerintah sendiri tidak berhasil meningkatkan produksi dengan menggunakan sumber-sumber yang masih ada untuk peningkatan pendapatan nasional. Indonesia juga tidak memiliki barang-barang ekspor lainnya kecuali hasil perkebunan. Karena defisit ini, kebijakan yang diambil oleh pemerintah saat itu (Kabinet Natsir) adalah melaksanakan industrialisasi.

Rencana melaksanakan program industrialisasi ini dikenal dengan Rencana Sumitro. Rencana ini ditekankan pada industri dasar, seperti pendirian pabrik-pabrik semen, pemintalan, karung, percetakan, dll. Akan tetapi karena masa kerja masingmasing kabinet terlalu singkat maka programnya pun selalu berganti-ganti sebelum program yang dicanangkan itu terlaksana dengan tuntas atau sempurna, maka hal ini juga yang menyebabkan tidak stabilnya situasi politik, dan sebagai awal dari kemerosotan ekonomi, inflasi, dan lambatnya pelaksanaan pembangunan.

Menurut Anwar Haryono wakil ketua fraksi Masyumi: ${ }^{43}$

...Rencana apa pun yang baik untuk membela kepentingan rakyat harus didukung, Partai Masyumi dalam perjuangannya baik di dalam maupun di luar Parlementer selalu mengutamakan kepentingan rakyat. Terkadang kedudukan Masyumi sebagai fraksi dalam parlementer juga berubah-ubah di mana sekali-kali duduk sebagai fraksi oposisi. Tetapi baik sebagai oposisi ${ }^{44}$ ataupun bukan tugas fraksi Masyumi adalah sama dan satu yaitu membela kepentingan rakyat. Kepentingan rakyat

\footnotetext{
${ }^{43}$ Surat Kabar Harian Abadi, Tahun ke-VIII, Tanggal 27 November 1958

44 Tentang keberadaan Partai Masyumi yang kemudian menjadi partai oposisi adalah karena diawali adanya tuntutan-tuntutan daerah untuk membuat dewa-dewan tersendiri. Seperti yang terjadi tanggal 20 Desember 1956 "Dewan Banteng" yang mengambil kekuaksaan di Sumatera Tengah, tanggal 22 Desember 1956 "Dewan Gajah" bangkit di Sumatera Timur, dan disusul tanggal 24 Desember 1956 "Dewan Gwrud DI Sumatera Selatan. Dengan munculnya dewan-dewan tersebut kabinet merasa perlu menghadapinya dengan kewibawaan Kepala Negara dengan satu perintah Panglima Tertinggi, walaupun pada akhirnya tidak menghasilkan apa-apa. Sejak itu Pimpinan Masyumi merasa tidak ada lagi ruang gerak bila tetap duduk dalam kabinet dan memutuskan akan lebih bermanfaat dengan melakukan tugas oposisi dalam parlemen, dengan mengeluarkan Statement PP Masyumi, Pimpinan Masyumi kemudian menyarankan agar diadakan saja Kabinet Presidentiil Sukarno Hatta. Pada tanggal 9 Januari 1957 Masyumi menarik menteri-menterinya dari kabinet. Lihat di M. Natsir, Capita Selecta, Jilid 2, PT. Abadi, Jakarta, 2008, hal. 29-35, dan Jilid 3, hal. 417 418, lihat juga Surat Kabar Harian Abadi, Tahun ke-VII, Januari 1957
} 
langsung tersinggung, dan langsung terasa, lebih-lebih kalau dirugikan. Kalau kepentingan rakyat dirugikan dengan tidak ragu-ragu fraksi Masyumi tampil ke depan walaupun ia sedang duduk sebagai fraksi pemerintahan. Kalau karena itu lalu pemerintah jatuh itu adalah resiko demokrasi boleh datang dan pergi, tapi kepentingan rakyat berada di atasnya.

Dari sekian banyak partaipartai Islam dalam memperjuangkan ekonomi rakyat, pada tahun 1950-an hanya Partai Masyumi yang mempunyai keahlian dalam bidang ekonomi. Banyak tokoh yang dibanggakannya dari partai Masyumi ini seperti Sjafruddin Prawiranegara, Jusuf Wibisono, Boerhanoeddin Harahap, dan Prof. Sunardjo. Sjafruddin Prawirwnegara pernah menjabat sebagai Gubernur Bank Indonesia pada tahun 1952, Burhanuddin pernah menjabat dalam Kementerian Perekonomian dalam Kabinet Ali Sastroamidojo II (1956-1958), dan Prof. Sunadjo adalah seorang lulusan Sekolah Tinggi Ekonomi di Rotterdam (Belanda), ia pernah menjadi sataf pengajar di Universitas Gadjah Mada (UGM) tahun 1950-an dan menjadi guru besar tahun 1954 dari universitas yang sama setelah menjabat di Kementerian Keuangan.

Ketika perekonomian Indonesia diarahkan menjadi ekonomi nasional tokoh-tokoh dari Partai Masyumi tersebut sangat berpengaruh dalam membina dan membangun ekonomi nasional tersebut. Seperti Jusuf Wibisono yang ketika menjabat sebagai ketua komisi negara, tahun 1956 menyetujui agar perusahaan tambang minyak dikelola oleh pemerintah Indonesia tidak lagi oleh Bataafse Petroleum Maatschappij (BPM), suatu perusahaan milik Belanda, tetapi kemudian persetujuan itu dibatalkan sepihak oleh Belanda. Pembatalan sepihak ini membuat para tokoh ekonomi Indonesia khususnya Partai Masyumi menjadi lebih hati-hati dalam program nasionalisasi ekonomi ini, berhati-hati tidak saja pada perusahaanperusahaan milik swasta luar negeri melainkan juga terhadap partai-partai atau juga golongan kiri yang radikal dalam memberikan kredit, mensikapi antikorupsi, dsb. Perdana Menteri Boerhanuddin Harahap dalam mensikapi tentang korupsi ini, ia mengeluarkan pernyataan pada tanggal 20 Agustus 1955 dengan mengatakan:

Untuk memperbaiki kembali keadaan yang tidak sehat di dalam masyarakat dan juga di kalangan pemerintahan sebagai akibat dari tindakan-tindakan korup oleh berbagai orang, maka pemerintah menganggap perlu untuk menjalankan tindakan-tindakan yang keras dan tegas. Tindakan-tindakan itu dijalankan bersandarkan hukum yang berlaku dengan menggunakan alat-alat kekuasaan negara yang sah dan melulu ditujukan kepada orang-orang yang dianggap bersalah menjalankan korupsi.

Pemerintah dengan ini menegaskan bahwa tindakan-tindakan yang dijalankan dalam hal ini sama sekali tidak mengandung maksud untuk ditujukan terhadap suatu partai politik atau terhadap suatu golongan masyarakat, akan tetapi ... semata-mata dimaksudkan untuk menuntut orangorang yang dianggap bersalah melanggar hukum dengan tidak memandang partai, golongan atau agama.

...apabila korupsi yang merajalela di berbagai kalangan itu dibiarkan saja, akan sangat merugikan rakyat dan negara,.... ${ }^{45}$

Perilaku $\begin{gathered}\text { korupsi } \\ \text { dengan }\end{gathered} \begin{array}{r}\text { adalah } \\ \text { tujuan }\end{array}$
bertentang
mensejahterakan rakyat, karena korupsi
adalah mengutamakan kepentingan

\footnotetext{
${ }^{45}$ Deliar Noer, Partai Islam..., op. cit., hal. 324 dan lihat Surat Kabar Harian Abadi, Tahun ke-V, Tanggal 22 Agustus 1955
} 
pribadi daripada kepentingan masyarakat. Dalam memperjuangkan ekonomi ummat Islam, Partai Masyumi selalu berhati-hati dalam melakukan kerja sama supaya tidak terjebak dalam kerjasma dengan orang yang berperilaku seperti itu. Mohammad Natsir selalu menyerukan kepada seluruh lapisan masyarakat, di antaranya bahwa:

Para pedagang dan pengusaha agar menyumbangkan tenaganya dengan sungguh-sungguh memecahkan persoalan perdagangan ekonomi untuk memperkuat potensi perjuangan kita, dengan menghindarkan diri dari tindakan-tindakan yang mungkin membantu musuh dalam usaha konsolidasinya di bidang ekonomi. ${ }^{46}$

Perilaku korupsi adalah perilaku kejahatan yang akan menyengsarakan ummat, menjadikan masyarakat hidup dalam kemiskinan, penderitaan, dan penindasan. Sementara menurut Mochammad Natsir bahwa orang yang berbudi luhur adalah orang yang beragama dan menghargai orang banyak. Seperti seluruh sistem yang dimajukan oleh Nabi Muhammad saw itu, yaitu untuk mengadakan masyarakat yang hidup dalam keagamaan yang baik dan tidak boleh membiarkan diri kita rela menerima kemelaratan dan kemiskinan. Diperintahkan supaya kita jangan melupakan nasib kita di atas dunia. Kita disuruh menggunakan apa yang ada di sekeliling kita dengan jalan mengubah kekuatan alam, barang-barang logam, hasil-hasil lautan, dan sebagainya. Semuanya itu adalah pemberian Tuhan untuk manusia. Semua itu dapat meninggikan kehidupan manusia, sehingga kehidupan itu jadi beragam dan bercahaya dan manusia dapat merasakan nikmatnya anugerah Ilahi. ${ }^{47}$

Tetapi dalam menikmati anugerah Tuhan itu, manusia juga

\footnotetext{
${ }^{46}$ M. Natsir, op. cit., Jilid 3, hal. 189

${ }^{47}$ M. Natsir, op. cit., Jilid 2, hal. 184
}

diingatkan bahwa dalam harta benda yang dimiliki seseorang ada hak orangorang miskin dan kaum du'afa, oleh karena itu menurut M. Natsir bahwa:

...dalam ajaran Islam dilarang menumpuk-numpuk harta yang on productief itu. Jangan ditumpukkan mas dan perak untuk dilihat dan dihitunghitung saja saban waktu, tapi masukkanlah dalam roda produksi, dalam produksi stelsel bagi menambah kebahagiaan dan kesejahteraan bersama. Diancam Tuhan orang yang menumpuknumpuk harta yang on produktief itu, yaitu orang-orang yaknizunzzahab, yaitu orang yang menyimpan-nyimpan mas dan perak dengan tidak produktif, tanpa menghasilkan apa-apa. (Al-Qur'an. Surat At Taubah: 34). Harta-harta itu mesti digerak dan diputarkan, agar orang-orang yang tidak bekerja mendapat pekerjaan dan agar besarnya produksi dapat mencukupi kebutuhan masyarakat. Atau dengan lain perkataan dalam pada modal harus dijadikan produktif, hendaklah pula para pemilik modal atau majikan, jangan dipimpin semata-mata oleh motif mencari untung saja, tapi harus mementingkan perkembangan dan keperluan-keperluan masyarakat. ${ }^{48}$

Oleh karena itu Mochammad Natsir sangat membenci praktek korupsi yang dilakukan oleh segolongan masyarakat. Korupsi adalah perilaku yang sangat merugikan kehidupan masyarakat banyak dan meruntuhkan perekonomian negara. Korupsi juga mengarahkan manusia untuk hidup berkelas-kelas yang tidak mengindahkan pada nasib rakyat.

Menurut M. Natsir bahwa:

Approach Islam terhadap persoalan ekonomi masyarakat ini tidak dengan mengobarkan kesumat dalam bentuk pertentangan kelas. Tetapi dengan jalan menumbuhkan rasa saling mengerti

${ }^{48}$ M. Natsir, op. cit., Jilid 2, hal 184-185 
antara orang-orang atau golongan yang mempunyai perhubungan kepentingan, dengan tidak mengakui adanya kelaskelas yang meruntuhkan keadaan. Timbulnya kekacauan sosial duni produksi, yang berakibat lahirnya serikat-serikat sekerja separti sekarang, adalah disebabkan oleh adanya eksploitasi yang tidak mengenal peri kemanusiaan oleh pihak majikan atau pemilik modal terhadap buruh, yang dalam pada menggunakan tenaga manusia dengan semau-maunya tidak mau memikul tanggung jawab atas kesejahteraan manusia yang diperas tenaga dan energinya itu. Dasar approach Islam terhadap masalah ini telah diletakkan oleh Nabi Basar Muhammad sendiri dengan sabdanya bahwa: "Tidak akan sempurna iman seseorang sebelum ia mencintai saudara sesamanya, sebagaimana ia mencintai dirinya sendiri". Atas dasar inilah bahwa golongan majikan dan golongan buruh adalah bukan golongan kelas yang berbeda yang masing-masing mewakili suatu kepentingan, ekslusif yang bertentangan satu dengan yang lain tidak akan dipertemukan. Islam menganggap majikan dan buruh kedua-duanya faktor industri yang masing-masingnya mempunyai fungsi, mempunyai tanggung jawab dan andil, yang sama pentingnya dalam menghasilkan barangbarang keperluan masyarakat. Kedua golongan ini mempunyai persamaan kepentingan dalam arti, bahwa kemunduran industri, baik disebabkan oleh menurunnya produksi tifitet tenaga buruh oleh karena jeleknnya keadaan kesehatan dan kesejahteraan buruh itu, atau disebabkan oleh tidak dapat dijualnya barang hasil industri tersebut oleh karena tidak seimbang penjualan dengan ongkos produksi yang begitu tinggi karena tuntutan-tuntutan buruh. Dihubungkan lagi dengan tenaga pembeli dari masyarakat, semua itu akan berakibat buruk dan merugikan kepada kepentingan majikan dan buruh itu sendiri pula. Oleh karena itu menurut Islam, dengan adanya perasaan tanggung jawab terhadap masyarakat dengan merasakan imbangan-imbangan kepentingan itu masalah pertentangan majikan dan buruh dapat diselesaikan atau dengan kata lain menumbuhkan kembali kesadaran akan tanggung jawab masing-masing dan saling mengerti di antara mereka. Buruh juga harus setia melaksanakan kerja, jangan mencuri jam "walmufuna bi'ahdihim", muslim itu harus menyempurnakan janjinya. (Al Baqarah: 177) Penyelesaian menurut Islam itu saling mencintai dan saling mengerti serta menghormati kepentingan pihak lain. Tidak memperbesar kebencian dan permusuhan tetapi harus menjalin hubungan yang harmonis, harus saling percaya dan tidak saling curiga mencurigai. ${ }^{49}$

Berdasarkan ini semua lapisan masyarakat harus memikul tanggung jawab sepenuhnya dalam mewujudkan kesejahteraan bersama. Dalam ajaran Islam tolong menolong untuk saling merasakan dan mengusahakan perbaikan dalam kepentingan bersama merupakan jalan terbaik untuk menuju taqwa dan menghindari dosa, sebagaimana diterangkan dalam Al-Qur'an surat AlMaidah ayat 2, yang artinya; ..."dan tolong menolonglah kamu dalam (mengerjakan) kebajikan dan taqwa, dan jangan tolong menolong dalam berbuat dosa dan permusuhan...."

Berdasarkan pernyataan tersebut menurut Mochammad Natsir dalam mengentaskan kemiskinan dan melaksanakan hidup yang harmonis maka, bahwa:

"Hanya dengan tenaga kaum lemah manusia itu mendapat pertolongan dari Allah untuk mencapai kemenangan sebagaimana dikatakan dalam Hadits Nabi Muhammad saw. innama

${ }^{49}$ M. Natsir, op. cit., Jilid 2, hal 188-191 
tunshiruna wa turzaquna bidu'afaihim (HR. Abu Dawud melalui Abu AdDarda) bahwa "kalian mendapat kemenangan dan kecukupan berkat orang-orang lemah di antara kalian. ${ }^{50}$

\section{Kesimpulan}

Dalam
sesungguhnya terlihat bahwa berdasarkan sumber-sumber sejarah yang dapat saya peroleh dari Surat Kabar Harian Abadi, penerbitanpenerbitan Masyumi, pidato-pidato anggota Partai Masyumi, khususnya pidato-pidato Mochammad Natsir, dan buku-buku yang sudah ditulis tentang Masyumi dapat direkonstruksi sebagai sejarah tentang bagaimana kiprah Partai Masyumi pada masa tahun 1950-an, terutama Mochammad Natsir. Mochammad Natsir tidak hanya berjuang di ranah politik tetapi berdasarkan temuan dari sumber-sumber tersebut menunjukkan bahwa ia juga aktif memberikan sumbangan pemikiran dan kebijakan tentang pentingnya pembangunan ekonomi dan kesejahteraan umat. Dengan demikian dapat disimpulkan bahwa Mochammad Natsir sangat peduli terhadap pembangunan ekonomi ummat.

Mochammad Natsir senantiasa memperjuangkan perbaikan nasib buruh, petani, para pegawai pemerintahan, dan sebagainya. Hal itu bagi Mochammad Natsir merupakan bagian yang tidak dapat dipisahkan dari perjuangan mencapai kemerdekaan secara utuh dan menyeluruh karena memperjuangkan nasib rakyat berarti menyusun sendisendi ekonomi dan sosial seluruhnya.

Dalam perjuangannya mengentaskan kemiskinan Mochammad Natsir selalu berdasarkan ajaran Islam, menganjurkan setiap individu itu wajib berusaha dan bekerja, seperti yang sudah

\footnotetext{
${ }^{50}$ M. Natsir, op. cit., Jilid 2, dan Surat Kabar Harian Abadi, Tanggal 6 Oktober 1951
}

dijelaskan dalam Al-Qur'an surat Ali Imron ayat 14. Sebagai anggota masyarakat juga wajib melaksanakan sumbangan sukarela (infaq dan shodaqoh) dan melakukan zakat, ini juga seperti yang dijelaskan dalam AlQur'an surat At- Taubah ayat 60 dan Adz-Dzariyat ayat 19. Dalam hal ini menurut Masyumi ummat Islam dalam mengentaskan kemiskinan wajib membantu kaum dhu'afa dan anggota masyarakat lainnya seperti dalam surat Al-Isro ayat 26.

Demi mencapai kesejahteraan, Mochammad Natsir selalu menyadarkan ummat Islam bahwa apa yang ada pada tangan seseorang itu adalah hakekatnya dari Allah dan manusia diwajibkan menyerahkan kekayaannya sesuai kadar yang ditentukan kepada sesamanya. Oleh sebab itu menurut Mochammad Natsir pemerintah juga berkewajiban memenuhi kebutuhan setiap warganya melalui sumber-sumber dana yang sah. Seperti yang terpenting di antaranya adalah pajak, baik dalam bentuk pajak perorangan, tanah, perdagangan, maupun pajak tanbahan lainnya yang ditetapkan pemerintah.

Maka menurut Mochammad Natsir, prilaku taat pajak dan dengan menekankan hukum zakat akan menimbulkan rasa persaudaraan, mengikis habis sifat-sifat kikir di dalam jiwa seseorang, serta melatihnya berjiwa dermawan, dan mengantarnya untuk mensyukuri nikmat Allah. Selain itu dapat menciptakan ketenangan dan ketenteraman bukan hanya pada penerima akan tetapi pada pemberi zakat juga. Islam mengajarkan kepada seluruh ummat Islam untuk berpartisipasi menanggulangi kemiskinan sesuai dengan kemampuannya.

Dalam memperjuangkan ekonomi ummat, Mochammad Natsir menyoroti para pelaku ekonomi, terutama menyangkut etika memperoleh harta, bahwa: 
"Pada prinsipnya tidak ada batas maksimal, sampai seberapa besar harta yang boleh dimiliki. Selama seorang pemilik berusaha dengan jalan yang halal dengan cara yang patut dan pantas, tidak bertentangan dengan kesejahteraan umum, seperti melakukan monopoli yang bisa menyempitkan kehidupan masyarakat umum, dia boleh mengembangkan harta bendanya sekuat tenaga." 51

Mengamati pernyataan dan peringatan Mochammad Natsir tersebut, maka tampak beberapa masalah penting yang harus diperhatikan: masalah cara memperoleh harta, masalah etika bagi pelaku ekonomi, dalam hal ini para pemilik modal dan para pekerja, terutama menyangkut hak dan kewajiban, masalah fungsi sosial dari harta tersebut yaitu untuk kesejahteraan ummat manusia, dan masalah perlu adanya perhatian serius terhadap petunjuk-petunjuk agama yang menyoroti kepentingan ekonomi. ${ }^{52}$

Dengan demikian Mochammad Natsir tidak hanya menggagas pemikiran secara teoritis, melainkan juga dibuktikan dengan kenyataan, seperti dalam bidang dakwah, penerbitan, pendidikan, sosial-ekonomi, kesehatan, kepesantrenan, kemasjidan, penelitian, pengembangan masyarakat, dan berbagai kegiatan di lingkungan cendekiawan muslim. Mochammad Natsir memprakarsai berdirinya pesantren Daarul Fallah yang didirikan di atas tanah seluas 20,5 hektar di desa Ciampea, Bogor, dan mengembangkan teknologi tepat guna dalam bidang pertanian, pengembangan koperasi, peternakan, kesehatan masyarakat terpadu yang dikoordinir oleh Yayasan Desa bahagia. Dengan program pendidikan yang terpadu antara ilmuilmu keagamaan dan teknologi pertanian, manajemen perkoprerasian,

${ }^{51}$ Thohir Luth, op. cit., hal. 92

${ }^{52}$ Thohir Luth, op. cit., hal. 92 perbengkelan dan berbagai ilmu keterampilan lainnya. Pesantren Daarul Fallah telah mempelopori kerja sama dengan pihak luar negeri semenjak tahun 1968, seperti dalam penyediaan fasilitas pendidikan, perbengkelan, peternakan, dsb. Ini merupakan usaha nyata di bidang sosial-ekonomi ummat Islam, sekalipun kemiskinan suit diatasi akan tetapi setidaknya dapat menawarkan peluang kerja dan mengembangkan perekonomian di berbagai sektor. ${ }^{53}$

Dengan memperhatikan

beberapa pernyataan Mochammad Natsir dalam memperjuangkan ekonomi ummat Islam sesungguhnya Paratai Masyumi telah menjalankan ajaran ekonomi Islam sebagaimana dalam pelaksanaan hukum zakat. Dalam Islam zakat adalah ibadah yang berkaitan dengan harta benda. Allah menjadikan harta benda sebagai sarana kehidupan untuk ummat manusia seluruhnya, karena zakat diarahkan untuk kepentingan bersama.

Dalam hal ini Mohammad Natsir menyoroti tentang hak milik manusia, bahwa:

Sesungguhnya Masyumi mengakui adanya hak milik dengan pengertian bahwa si pemilik berkewajiban terhadap masyarakat, supaya mempergunakannya untuk kemakmuran masyarakat itu. Yang dilarang adalah kalau hak milik itu dipergunakan untuk penindasan. Selain itu selain si pemilik harus membayar pajak kepada negara, juga sebagai seorang Islam berkewajiban membayar zakat dan fitrah. $^{54}$

\footnotetext{
${ }^{53}$ Thohir Luth, op. cit., 93-94

${ }^{54}$ M. Natsir, op. cit., Jilid 2, hal. 425-426
} 


\section{Daftar Sumber}

\section{Sumber Surat Kabar dan Majalah}

Abadi, Surat kabar milik Partai Masyumi, 19501960

Berita Masyumi, 1950-1952

\section{Sumber Primer yang Diterbitkan}

Natsir, M. Capita Selecta, Jilid 2, Cetakan Pertama 1957 dan Jilid 3, PT. Abadi, Jakarta 2008

\section{Buku}

Benda, Harry J., terj., Bulan Sabit dan Matahari Terbit, Jakarta, Pustaka, 1980

Miriam Budiardjo, Dasar-Dasar Ilmu Politik, Edisi Revisi, PT. Gramedia Pustaka Utama, Jakarta, 2008

Eriyanto, Analisis Wacana, Yogyakarta, LKIS, 2003

Encyclopaedia of Social Sciences, Vol. 13-14

Feith, Herbert \& Lance Castles, ed., Pemikiran Politik Indonesia 1945-1965, LP3ES, Jakarta, 1995

Flournoy, Don Michael, Analisis Isi Surat Kabar Indonesia, Yogyakarta, UGM Press, 1989 ,

Geertz, Clifford, Abangan, Santri, Priyayi dalam Masyarakat Jawa. Terj., Jakarta, Pustaka Jaya, 1983

Hakiem, Lukman, ed., 100 tahun Mohammad Natsit: Berdamai dengan Sejarah: Berdamai dengan Sejarah, Penerbit Republika, Jakarta, 2008

Husein Heikal, Muhammad, Pemerintah Islam, Terj., Pustaka Firdaus, Jakarta, 1990
Iskandar, Muhammad, Para Pengemban Amanah: Pergulatan Pemikiran Kyai dan Ulama di Jawa Barat 1900-1950, Yogyakarta, Matabangsa, 2001

Ismail, Ibnu Qoyyim, Kyai Penghulu Jawa: Peranannya di Masa Kolonial, Gema Insani Pers, Jakarta, 1997

Kartodirdjo, Sartono, Pemikiran dan Perkembangan Historiografi Indonesia: Suatu Alternatif, Jakarta, Gramedia, 1982

Kartodirdjo, Sartono, Pendekatan Ilmu Sosial dalam Metodologi Sejarah, Jakarta, Gramedia, 1992

Kartodirdjo, Sartono, Pengantar Sejarah Indonesia baru: Sejarah Pergerakan Nasional, dari Kolonialisme sampai Nasionalisme, Jilid 2, Jakarta, Gramedia

Korver, A.P.E., Sarekat Islam: Gerakan Ratu Adil?, Jakarta, Grafiti Pers, 1985

Kuntowijoyo, Budaya dan Masyarakat, Tiara Wacana, Yogyakarta, 1999

Paradigma Islam: Sebuah Interpretasi Untuk Aksi, Bandung, MIzan, 1991

'Kebudayaan Indonesia Kontemporer', Makalah Simposium Martabat Manusia Indonesia, Yayasan Sudjatmoko, Jakarta, 23 Januari 1991

Leirissa, R.Z., et. al., Sejarah Perekonomian Indonesia, Proyek Inventarisasi dan Dokumentasi Sejarah Nasional, Departemen Pendidikan dan kebudayaan RI, Jakarta, 1996

Luth, Thohir, M. Natsir: Dakwah dan Pemikirannya, Jakarta, Gema Insani Press, 1999

Mubyarto, 'Islam menghadapi Kemiskinan dan Kesenjangan’, Makalah Simposium Festival 
Istiqlal, dalam Panduan Simposium: Islam dan Kebudayaan Indonesia Dulu, Kini, dan Esok, Jakarta, Gedung Indosat, 1991

Nakamura, Mitsuo, Bulan Sabit Muncul dari Balik Pohon Beringin: Studi tentang Pergerakan Muhammadiyah di Kotagede, Yogyakarta, UGM Press, 1983

Naquib, Al Atas, Muh., Islam dalam Sejarah dan Kebudayaan Melayu, Bandung, Mizan, 1990

Nasution, Harun, Pembaharuan dalam Islam: Sejarah Pemikiran dan Gerakan, Jakarta, Bulan Bintang, 1991

Natsir, M. Capita Selecta, Jilid 2 dan Jilid 3, PT. Abadi, Jakarta 2008

Niel, Robert van, Munculnya Elit Modern Indonesia, Jakarta, Pustaka Jaya

Noer, Deliar, Gerakan Modern Islam di Indonesia 1900-1942, Jakarta, LP3ES, 1991

Mohammad Hatta: Biografi Politik, LP3ES, Jakarta, 1990

, Partai Islam di Pentas Nasional: Kisah dan Analisis Perkembangan Politik Indonesia 1945-1965, Bandung, Mizan, 2000

Pijper, G. F., Penelitian tentang Agama Islam di Indonesia 1930-1950, terj. Jakarta, UI Press, 1992
Poesponegoro, Marwati Djoened dan Nugroho Notosusanto, ed., Sejarah Nasional Indonesia, Jilid VI, Jakarta, Balai Pustaka, 1984

Ricklefs, M. C., Sejarah Indonesia Modern, terj., Yogyakarta, UGM Press, 1994

1200-2004, Serambi, Jakarta, 2001

Stoddarrd, L., Dunia Baru Islam, Jakarta, Percetakan Negara, 1966

Sumarjan, Selo, Perubahan Sosial di Yogyakarta, Yogyakarta, UGM Press, 1993

Suminto, Aqib, Politik Islam Hindia Belanda: Het Kantoor voor Indlandsche Zakken, Jakarta, LP3ES, 1996

Supomo, Prof. Dr., Undang-undang Dasar Sementara Republik Indonesia, Djakarta, 1950

Surjomihardjo, Abdurrahman, ed., Beberapa Segi Perkembangan Sejarah Pers di Indonesia, Jakarta, Kompas, 2002

Tanthowi, Pramono U., Kebangkitan Politik Kaum Santri: Islam dan Demokratisasi di Indonesia 1990-2000, PSAP, Jakarta, 2005

Welirang, Franciscus, Revitalisasi Republik: Perspektif Pangan dan Kebudayaan, Grafindo, Jakarta, 2007 